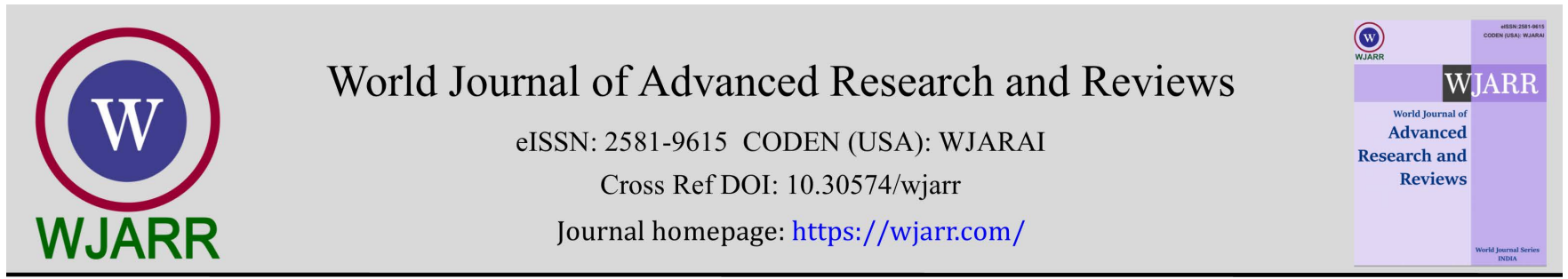

(RESEARCH ARTiClE)

Check for updates

\title{
New genomic regions for resistance to anthracnose (Colletotrichum lindemuthianum) through GBS-based genome-wide association study in common bean (Phaseolus vulgaris)
}

Mariana Vaz Bisneta 1, ${ }^{*}$, Maria Celeste Gonçalves-Vidigal ${ }^{1}$, Pedro Soares Vidigal Filho ${ }^{1}$, Júlio Cesar Ferreira Elias ${ }^{1}$, Giseli Valentini ${ }^{1}$, Laíze Raphaelle Lemos Lima ${ }^{1}$, Maria da Conceição Martiniano-Souza ${ }^{2}$, Andrea Ariani ${ }^{3}$ and Paul Gepts ${ }^{3}$

1 Universidade Estadual de Maringá, Departamento de Agronomia, Maringá, Brazil.

2 Instituto Agronômico de Pernambuco, Recife, Brazil.

${ }^{3}$ University of California, Department of Plant Sciences / MS1, Section of Crop \& Ecosystem Sciences, Davis, USA.

World Journal of Advanced Research and Reviews, 2021, 12(01), 020-040

Publication history: Received on 24 August 2021; revised on 28 September 2021; accepted on 30 September 2021

Article DOI: https://doi.org/10.30574/wjarr.2021.12.1.0493

\begin{abstract}
The most effective strategy to manage bean anthracnose (ANT), caused by Colletotrichum lindemuthianum, is the use of resistant cultivars. This study aimed to evaluate resistance reactions of common bean accessions to $C$. lindemuthianum races 2, 9 and 1545, and to perform genome-wide association study (GWAS). Hence, 89 accessions were phenotyped and genotyped through genotyping by sequencing (GBS). As a result, 48 accessions resistant to all evaluated races were identified. Moreover, single-nucleotide polymorphisms (SNP) significantly associated with resistance were identified in new regions of chromosomes Pv03, Pv05 and Pv06, and also at the beginning of Pv04 and end of Pv11, where other resistance genes have been previously found. In reference genome these regions contain model genes encoding resistance proteins as kinases, leucine-rich repeats, receptor-like protein, copper transport protein, pentatricopeptide repeats, calcium-dependent protein kinases, and ethylene-responsive transcription factors. The genomic regions associated to ANT resistance found in this study should be validated for further use in marker assisted selection and gene pyramiding. Together with new sources of ANT resistance our findings show promise for further crop improvement.
\end{abstract}

Keywords: GWAS; GBS; Colletotrichum lindemuthianum; Anthracnose; Resistance sources; Candidate genes

\section{Introduction}

Common bean is the most important legume for direct human consumption. As functional foods, beans are low in fat and high in fiber content [1]. They also provide essential proteins for human nutrition and are an important source of vitamins and minerals, such as iron, phosphorus, magnesium, manganese, zinc, copper, and calcium [2]. Common bean production can be severely affected by diseases. Anthracnose (ANT), caused by Colletotrichum lindemuthianum (Sacc. \& Magnus) Briosi \& Cavara, is a serious seed borne disease. Under disease-promoting conditions, such as high humidity and low temperature, bean anthracnose can result in yield losses up to 100 percent [3].

Adoption of certified seeds, crop rotation, and seed and foliar fungicide treatment are helpful in disease management. Nevertheless, the use of resistance cultivars is the most effective and ecologically sustainable strategy to manage bean anthracnose [4]. Studies in common bean segregating populations have already allowed the identification of more than

\footnotetext{
*Corresponding author: Mariana Vaz Bisneta; Email: marianavazbisneta@hotmail.com

Universidade Estadual de Maringá, Departamento de Agronomia, Maringá, Brazil. 
20 ANT resistance loci identified by the genetic symbol Co. Anthracnose resistance genes have been mapped on chromosomes Pv01, Pv02, Pv03, Pv04, Pv07, Pv08, Pv09, and Pv11 [5, 6, 7].

Genome-wide association mapping is an important approach for identifying the genetic basis of phenotypic variation [8]. This methodology, also called whole-genome scan, tests the association of marker loci distributed across a genome and a specific trait (phenotype), the assumption being that the marker loci either cause phenotypic variation or are in linkage disequilibrium with the causal locus [9]. Advances in sequencing technologies and variant detection algorithms have allowed the use of genomic variants in high-throughput studies such as GWAS, along with high-density singlenucleotide polymorphism (SNP), which favor the identification of small haplotype blocks that are significantly correlated with trait variation [10].

Traditional gene mapping uses populations derived from only two parents, with limited amount of genetic variation and relatively few recombination events. GWAS, however in contrast, uses large populations with wide natural variation and takes advantage of recombination events over multiple generations in high-resolution mapping $[8,11]$.

With the availability of a high-quality reference genome, GWAS became a powerful tool to identify resistance loci in common bean and provides the basis for further gene mapping. Genome-wide association studies aiming at the identification of anthracnose resistance loci have been conducted for common bean. Different ANT races were evaluated, and SNPs and quantitative resistance loci have been found on chromosomes Pv01, Pv02, Pv03, Pv04, Pv05, Pv06, Pv07, Pv08, Pv10 and Pv11 [12, 13, 14, 15, 16, 17]. Since an ANT resistance locus was also found in Pv09 in a complementary mode of action in the 'Cornell 49242' cultivar [5], all common bean chromosomes exhibit anthracnose resistance.

C. lindemuthianum is a highly variable pathogen. According to Nunes et al. (2021) [18], 298 different C. lindemuthianum races have been reported in 29 countries. Padder et al. (2017) [4] identified the occurrence of 182 races worldwide. Among the mechanisms that cause pathogen variability, we can highlight the co-evolution process between common bean and $C$. lindemuthianum. In general, Mesoamerican races are virulent on common bean cultivars from both Andean and Mesoamerican gene pools; however, Andean races are more virulent on common beans from the Andean pool [19]. Also, mutation, parasexual recombination, and introduction of new races into local populations are additional mechanisms that create variability [20]. As a result, resistant cultivars can become susceptible due to the appearance of new anthracnose races. Thus, the broad variability of the ANT pathogen requires the development of different cultivars with wide and durable resistance.

C. lindemuthianum race 2 is an Andean race that, across the 12 differential cultivars proposed by Pastor-Corrales (1991) [21], attacks only Michigan Dark Red Kidney (MDRK) which possesses the Co-1 gene. Race 2 has been identified in Argentina, Brazil, Bulgaria, Colombia, Dominican Republic, Ecuador, Greece, India, Kenya, Mexico, Peru, Tanzania, Turkey, Uganda, and the United States $[4,18]$. The fact that this race is widely found in several countries, including some of the largest common bean producers, requires attention and highlights the importance of the development of resistant cultivars in order to prevent its spread.

Race 9 is a Mesoamerican race that breaks the resistance of the differential cultivars Michelite (Co-11) and Cornell 49242 (Co-2). This race is also widely distributed, having already been found in Argentina, Brazil, Burundi, Colombia, Costa Rica, Dominican Republic, Ecuador, Guatemala, Honduras, Mexico, Peru, Tanzania, and the United States [4, 18].

Anthracnose pathogen race 1545 is able to infect the following differential cultivars: Michelite (Co-11), Cornell 49242 (Co-2), TU (Co-5), and AB 136 (Co-6). This race was identified in Colombia, Costa Rica, Guatemala, Honduras, Mexico, and Nicaragua $[4,18]$. Given the above, seeking new anthracnose sources of resistance is a constant aim for common bean breeding programs. That effort also includes mapping new resistance genes. Molecular markers linked to resistance genes may be used in the development of new common bean cultivars by pyramiding different resistance genes. Thus, the objective of this study was to evaluate the resistance reaction of the common bean accessions and to identify chromosome regions associated with $C$. lindemuthianum races 2, 9, and 1545 through GBS-based genome-wide association approach of recently collected landraces from different parts of the bean-growing region in Brazil.

\section{Material and methods}

\subsection{Plant material and genotyping}

Plant material used in this study is part of the gene bank collection from the Núcleo de Pesquisa Aplicada à Agricultura (Nupagri), Universidade Estadual de Maringá (Brazil). A total of 89 common bean accessions, including cultivars and 
landraces, were collected in the Brazilian common bean growing regions in the states of Mato Grosso, Paraíba, Paraná, Pernambuco, and Sergipe (Figure 1, S1 Table). These accessions were previously classified using the molecular marker BMd-2 for phaseolin [22], resulting in 29 Andean and 60 Mesoamerican accessions.

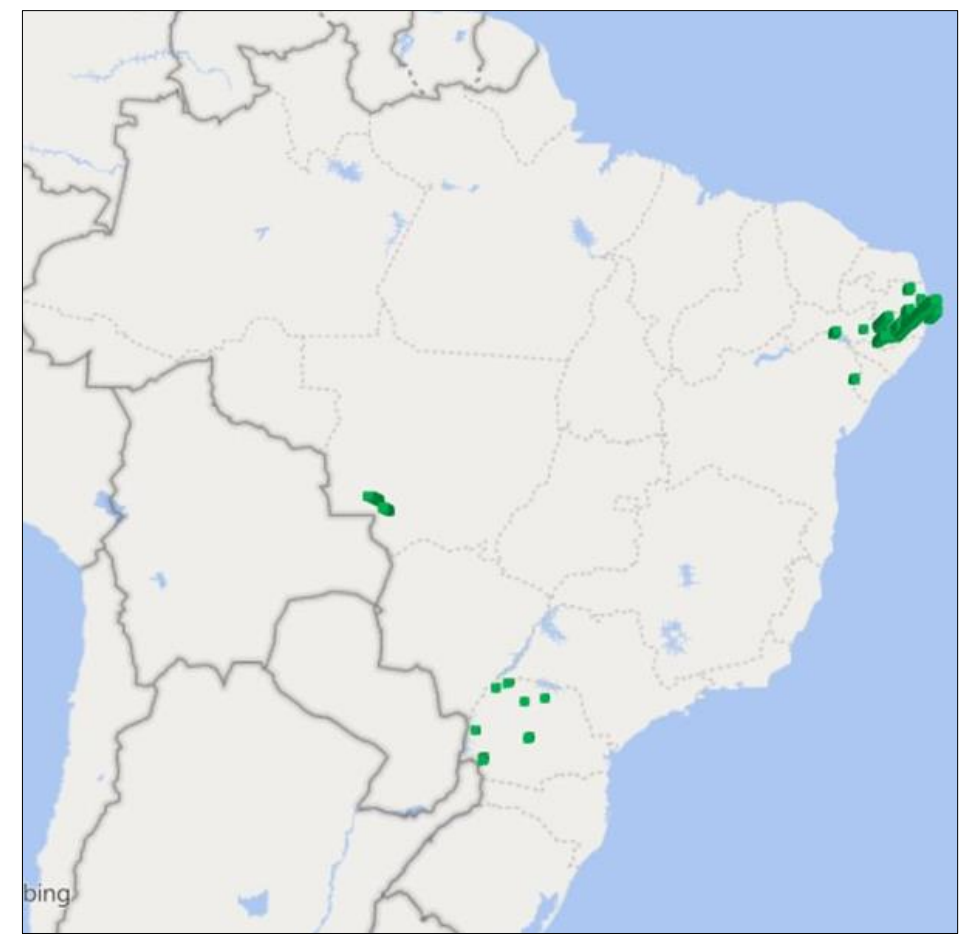

Figure 1 Brazilian regions where common bean accessions were collected

The accessions were genotyped using genotyping-by-sequencing (GBS) at the University of California Davis Genome Center. DNA was collected from young leaves tissues and extracted following the Pallotta et al. (2003) [23] extraction protocol with modifications to eliminate RNA. The DNA quality was checked using spectrometry (Nanodrop Lite, Thermo Fisher Scientific) and electrophoresis (1\% agarose gel). DNA with a A260/A280 absorbance ratio higher than 1.7 and without degradation was used for library preparation. Library preparation for GBS followed Elshire et al. (2011) protocol [24] using the CviAII restriction enzyme (CATG recognition site) and DNA with a specific barcode adapter for each accession. CviAII was used as the most suitable enzyme for GBS given the smaller genome size of common bean and the broader genome coverage provided by this enzyme compared to ApeKI [25]. The ligation step was conducted using only $0.6 \times$ of the ligation buffer. PCR amplifications were performed for fragment enrichment followed by adapter dimers check with Experion DNA analysis kit (Biorad). Sequencing was performed in HiSeq 2000 flow cell using the 50 bp protocol.

Sequences were aligned to the common bean reference genome v1.0 (landrace G19833) [26] using BWA [27]. In the filtering process, only SNPs that showed minor allele frequency (MAF) $>0.05$, a minimum quality $>10$, and a mean read depth, across all lines, ranging from 5 to 1000, were included. Base call recalibration was performed with ReQON in R software [28]. Variants were called with SAMtools and filtered with VCFtools.

\subsection{Phenotypic evaluation of anthracnose}

Phenotypic evaluation was conducted at Nupagri, Universidade Estadual de Maringá. A total of 10 seeds per accession were surface disinfected with $1.5 \% \mathrm{NaClO}$ for one minute, water rinsed, then sown in trays containing substrate and maintained under greenhouse conditions. Anthracnose races 2, 9 and 1545 belonging to Nupagri's mycology collection were confirmed by inoculation into the set of 12 common bean differential cultivars [21]. During population evaluation, differential cultivar PI 207262 was used as resistant control for all races while MDRK was used as susceptible control for race 2 and Michelite was the susceptible control for races 9 and 1545. Each race was evaluated twice in a separated experimental.

Inocula of $C$. lindemuthianum were obtained following the methodology by Cárdenas et al. (1964) [29]. The mycelium was grown in petri dishes containing potato dextrose agar medium. Small pieces of the mycelium were transferred to 
sterilized young pods of snap beans placed in test tubes and incubated at $22^{\circ} \mathrm{C}$ for 14 days in darkness to promote sporulation. The resulting spores were suspended in sterile and distilled water, and inoculum concentration was adjusted to $1.2 \times 10^{6}$ conidia $\mathrm{mL}^{-1}$ using a hemocytometer (Neubauer chamber) in the microscope. Fifteen-day-old seedlings (10 plants per accession) were spray-inoculated with each race separately on the underside of the leaves.

Inoculated plants were transferred to a mist chamber and maintained at $>95 \%$ relative humidity, $20 \pm 2^{\circ} \mathrm{C}$ temperature, and $12 \mathrm{~h} 680$ lux light and $12 \mathrm{~h}$ darkness, for a total of 72 hours (three days). Over the following seven days, the inoculated plants were maintained in benches with the same controlled humidity, temperature, and luminosity. Anthracnose disease symptoms were visually evaluated according to Pastor-Corrales et al. (1995) [30] severity scale. Plants with disease reaction scores between 1 and 3 were considered resistant, whereas plants with scores from 4 to 9 were considered susceptible [30].

A resistance index was calculated for each accession, which consisted of the ratio of the number of races to which the access was resistant to the total number of races evaluated. Likewise, a pathogenicity index was calculated for each evaluated race, which consisted of the ratio of the number of accessions susceptible to that race to the total number of accessions evaluated.

\subsection{Genome-wide association analysis}

Association analysis was carried out in TASSEL software version 5.2.50 [31]. The population structure matrix, which describes the percent subpopulation parentage for each line in the analysis, was obtained by principal component analysis (PCA). The kinship matrix (K) was calculated to account for individual relatedness. GWAS was performed using mixed linear model (MLM) following the equation:

$$
Y=X \alpha+P \beta+K \mu+\varepsilon
$$

where $Y$ is the vector of the phenotype; $X$ is the incidence matrix of the independent vector $\alpha$ of SNPs fixed effect; $P$ is the incidence matrix of the independent vector $\beta$ of the population structure fixed effect; $K$ is the incidence matrix of the independent vector $\mu$ of the relative kinship random effect; and $\varepsilon$ is the error term assumed to be normally distributed with a zero mean. SNP p-value $<0.001$ was defined as a threshold to declare a significant association with anthracnose resistance.

\subsection{Functional annotation}

Common bean gene models within $100 \mathrm{kbp}$ upstream and downstream of the significant markers were taken into account for candidate gene searches. The position of each SNP was sought after in the reference bean genome (G19833 version 1.1.) [26] available at NCBI and www.phytozome.org. The gene functional annotation was identified in Phytozome (http://phytozome.jgi.doe.gov) to infer the possible role of the gene in conferring anthracnose resistance.

\section{Results and discussion}

\subsection{Genetic diversity of the common bean population}

Through GBS it was possible to obtain genotypic information of the 89 common bean accessions in 28,823 SNPs distributed over the 11 bean chromosomes (Table 1). The population structure obtained by Principal component analysis (PCA) data revealed that the accessions were clustered into two distinct groups, which corresponded to either the Andean (29 accessions) or Mesoamerican (60 accessions) gene pool (Figure 2). The first (PC1) principal component explained $92 \%$ of the variation among accessions and separated the Mesoamerican and Andean accessions. The second principal component explained $1 \%$ of the total variation. It was responsible for distinguishing the Mesoamerican accession, which were more diverse than the Andean accessions, as shown by the high dispersion of the points on the two-dimensional plane (Figure 2). 
Table 1 Length in base pairs, total number of SNPs per chromosome, per Megabase in each chromosome and interval in kilobase per SNP for the 11 chromosomes of common bean accessions in Brazil genotyped through GBS

\begin{tabular}{|l|l|c|c|c|}
\hline Chromosome & Length (bp) & No. SNPs & SNPs/Mb & kb/SNP \\
\hline Pv01 & $52,035,450$ & 3269 & 62.82 & 15.91 \\
\hline Pv02 & $48,839,311$ & 3651 & 74.75 & 13.37 \\
\hline Pv03 & $52,058,115$ & 3262 & 62.66 & 15.95 \\
\hline Pv04 & $44,941,012$ & 1788 & 39.78 & 25.13 \\
\hline Pv05 & $40,643,363$ & 2269 & 55.82 & 17.91 \\
\hline Pv06 & $31,956,823$ & 2304 & 72.09 & 13.87 \\
\hline Pv07 & $51,437,727$ & 2266 & 44.05 & 22.69 \\
\hline Pv08 & $59,476,018$ & 2276 & 38.26 & 26.13 \\
\hline Pv09 & $37,392,701$ & 3310 & 88.51 & 11.29 \\
\hline Pv10 & $42,953,733$ & 1660 & 38.64 & 25.87 \\
\hline Pv11 & $50,209,006$ & 2768 & 55.12 & 18.13 \\
\hline Total & $511,943,259$ & 28,823 & & \\
\hline Average & & & 57.5 & 18.75 \\
\hline
\end{tabular}

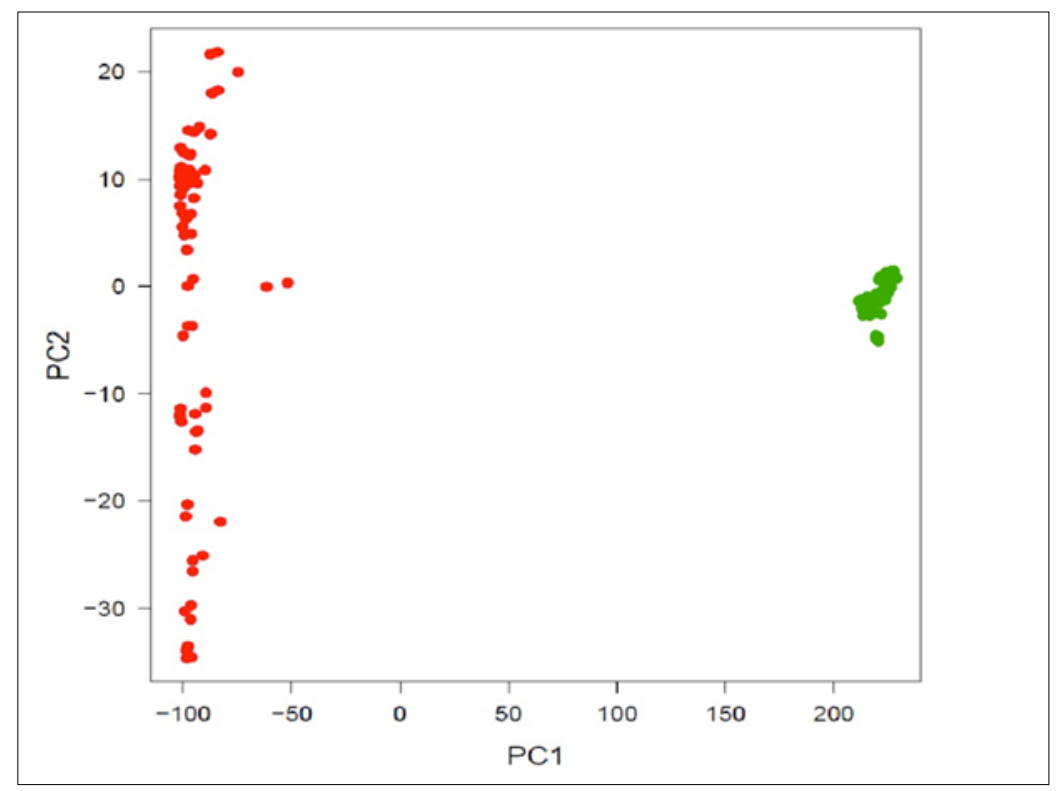

Figure 2 Plot of the genotypic variability of 89 common bean accessions through principal component analysis using 28,823 SNPs

\subsection{Anthracnose resistance}

Disease reaction of each accession, Resistance and Pathogenicity Index (RI and PI) are presented in Tables 2 and 3. Among Andean accessions, races 2 and 1545 both showed a $7 \%$ PI while, in Mesoamerican accessions, those races had indexes of $50 \%$ and $53 \%$, respectively. As for race 9, the PI was $3 \%$ in Andean beans and $52 \%$ in Mesoamericans accessions. Thus, Andean accessions presented an overall higher resistance index compared to the Mesoamerican accessions and, for that reason, they are a valuable source of anthracnose resistance. 
Table 2 Andean common bean disease reaction (Resistant or Susceptible) against C. lindemuthianum races 2, 9 and 1545. Accession's resistance index (\%) and races pathogenicity index (\%)

\begin{tabular}{|c|c|c|c|c|c|c|c|}
\hline \multirow{2}{*}{ Accession ID } & \multirow{2}{*}{ Accession name } & \multirow{2}{*}{ Origin 1} & \multirow{2}{*}{$\begin{array}{l}\text { Gene } \\
\text { pool }\end{array}$} & \multicolumn{3}{|c|}{ C. lindemuthianum races } & \multirow{2}{*}{$\begin{array}{l}\text { Resistance } \\
\text { index (\%) }\end{array}$} \\
\hline & & & & 2 & 9 & 1545 & \\
\hline BL_2 & Cocão & $\mathrm{PE}$ & A & $\mathrm{R}$ & $\mathrm{R}$ & $\mathrm{R}$ & 100 \\
\hline BL_3 & Bagajó & $\mathrm{SE}$ & A & $\mathrm{R}$ & $\mathrm{R}$ & $\mathrm{R}$ & 100 \\
\hline BL_5 & Canarinho & $\mathrm{PE}$ & A & $\mathrm{R}$ & $\mathrm{R}$ & $\mathrm{R}$ & 100 \\
\hline BL_7 & Chita Fina Verdadeiro & $\mathrm{PE}$ & $A$ & S & $\mathrm{R}$ & $\mathrm{S}$ & 33.33 \\
\hline BL_8 & Jaula & $\mathrm{PE}$ & A & $\mathrm{R}$ & $\mathrm{R}$ & $\mathrm{R}$ & 100 \\
\hline BL_9 & Pintado & $\mathrm{PE}$ & $A$ & $\mathrm{R}$ & $\mathrm{R}$ & $\mathrm{R}$ & 100 \\
\hline BL_11 & Praia & $\mathrm{SE}$ & A & $\mathrm{R}$ & $\mathrm{R}$ & $\mathrm{R}$ & 100 \\
\hline BL_12 & Camarão & $\mathrm{PE}$ & $A$ & $\mathrm{R}$ & $\mathrm{R}$ & $\mathrm{R}$ & 100 \\
\hline BL_13 & BSF-1 & $\mathrm{PE}$ & $A$ & $\mathrm{R}$ & $\mathrm{R}$ & $\mathrm{R}$ & 100 \\
\hline BL_15 & BSF-3 Fogo na serra & $\mathrm{PE}$ & $A$ & $\mathrm{R}$ & $\mathrm{R}$ & $\mathrm{R}$ & 100 \\
\hline BL_27 & Mulatão & $\mathrm{PE}$ & $A$ & S & $\mathrm{S}$ & $\mathrm{S}$ & 0 \\
\hline BL_74 & CLPE53 & $\mathrm{PE}$ & $A$ & $\mathrm{R}$ & $\mathrm{R}$ & $\mathrm{R}$ & 100 \\
\hline BL_75 & CLPE54 & $\mathrm{PE}$ & $A$ & $\mathrm{R}$ & $\mathrm{R}$ & $\mathrm{R}$ & 100 \\
\hline BL_77 & CLPE56 & $\mathrm{PE}$ & A & $\mathrm{R}$ & $\mathrm{R}$ & $\mathrm{R}$ & 100 \\
\hline BL_78 & CLPE58 & $\mathrm{PE}$ & $\mathrm{A}$ & $\mathrm{R}$ & $\mathrm{R}$ & $\mathrm{R}$ & 100 \\
\hline BL_79 & CLPE60 & $\mathrm{PE}$ & $A$ & $\mathrm{R}$ & $\mathrm{R}$ & $\mathrm{R}$ & 100 \\
\hline BL_93 & CLPE88 & $\mathrm{PE}$ & $A$ & $\mathrm{R}$ & $\mathrm{R}$ & $\mathrm{R}$ & 100 \\
\hline BL_94 & CLPE85 & $\mathrm{PE}$ & $A$ & $\mathrm{R}$ & $\mathrm{R}$ & $\mathrm{R}$ & 100 \\
\hline BL_165 & Pitanga & PR & A & $\mathrm{R}$ & $\mathrm{R}$ & $\mathrm{R}$ & 100 \\
\hline BL_166 & Corinthiano & $\mathrm{PR}$ & A & $\mathrm{R}$ & $\mathrm{R}$ & $\mathrm{R}$ & 100 \\
\hline BL_167 & Perla & Argentina & A & $\mathrm{R}$ & $\mathrm{R}$ & $\mathrm{R}$ & 100 \\
\hline BL_168 & Jalo Vermelho & PR & $A$ & $\mathrm{R}$ & $\mathrm{R}$ & $\mathrm{R}$ & 100 \\
\hline BL_170 & Jalo Listras Pretas & $\mathrm{PR}$ & $A$ & $\mathrm{R}$ & $\mathrm{R}$ & $\mathrm{R}$ & 100 \\
\hline BL_171 & Jalo EEP 558 & MG & $A$ & $\mathrm{R}$ & $\mathrm{R}$ & $\mathrm{R}$ & 100 \\
\hline BL_172 & BGF 20 & $\mathrm{PR}$ & A & $\mathrm{R}$ & $\mathrm{R}$ & $\mathrm{R}$ & 100 \\
\hline BL_178 & Perry Marrow & NA & $A$ & $\mathrm{R}$ & $\mathrm{R}$ & $\mathrm{R}$ & 100 \\
\hline BL_199 & Enxofre & $\mathrm{PE}$ & $A$ & $\mathrm{R}$ & $\mathrm{R}$ & $\mathrm{R}$ & 100 \\
\hline BL_220 & Jalo Pintado 2 & $\mathrm{PR}$ & A & $\mathrm{R}$ & $\mathrm{R}$ & $\mathrm{R}$ & 100 \\
\hline BL_221 & AND 277 & NA & $A$ & $\mathrm{R}$ & $\mathrm{R}$ & $\mathrm{R}$ & 100 \\
\hline \multicolumn{4}{|c|}{ Pathogenicity Index (\%) } & 6.90 & 3.45 & 6.90 & \\
\hline
\end{tabular}

${ }^{1} \mathrm{PE}=$ Pernambuco, $\mathrm{SE}=$ Sergipe, $\mathrm{PR}=$ Paraná, $\mathrm{MG}=$ Minas Gerais, NA=not available.

Among the 89 accessions evaluated, 54\% were resistant to C. lindemuthianum races 2, 9 and 1545, wherein 27 were from the Andean domesticated gene pool and 21 were Mesoamerican. All the Andean beans used in this study can be used to obtain resistant cultivars to anthracnose caused by the aforementioned $C$. lindemuthianum races, except the Mulatão, and Chita Fina Verdadeiro accessions. 
Regarding Mesoamerican sources of resistance, Rosinha Claro, Balinha, Brilhoso, IPA 1, Mulatinho de Cacho, Flor Azul, Laje, CLPE17, CLPE32, CLPE40, CLPE41, CLPE44, CLPE45, CLPE55, CLPE68, CLPE74, Awauna UEM, UEMT 50G2, Sempre Assim, MT 55, and MT 79 can be used as donors of resistant genes against races 2, 9 and 1545. For resistance against race 2 only, the following Mesoamerican cultivars can be used: Caiaminha, CLPE80, CLPE81, CLPE87, CLPE89, CLPE94, CLPE96, Juriti, MT57G1. Mesoamerican cultivars that showed resistance to race 9 were: CLPE47, CLPE80, CLPE81, CLPE86, Juriti, Bico de Ouro, BG-18, and MT 73G1. Finally, the following Mesoamerican sources were resistant to race 1545: MT 57G1, Bico de Ouro, BG-9, BG-13, MT 73G1, CLPE3, and CLPE21.

Table 3 Mesoamerican common bean disease reaction (Resistant or Susceptible) against C. lindemuthianum races 2, 9 and 1545. Accession's resistance index (\%) and races pathogenicity index (\%)

\begin{tabular}{|c|c|c|c|c|c|c|c|}
\hline \multirow{2}{*}{ Accession ID } & \multirow{2}{*}{ Accession name } & \multirow[t]{2}{*}{ Origin $^{1}$} & \multirow{2}{*}{ Gene pool } & \multicolumn{3}{|c|}{ C. lindemuthianum races } & \multirow{2}{*}{$\begin{array}{l}\text { Resistance } \\
\text { index (\%) }\end{array}$} \\
\hline & & & & 2 & 9 & 1545 & \\
\hline BL_1 & Brígida & $\mathrm{PE}$ & M & $S$ & $\mathrm{~S}$ & $S$ & 0 \\
\hline BL_6 & Rosinha Claro & $\mathrm{PE}$ & M & $\mathrm{R}$ & $\mathrm{R}$ & $\mathrm{R}$ & 100 \\
\hline BL_10 & Balinha & $\mathrm{PE}$ & M & $\mathrm{R}$ & $\mathrm{R}$ & $\mathrm{R}$ & 100 \\
\hline BL_14 & BSF-2 Pingo de Ouro & $\mathrm{PE}$ & $M$ & $S$ & $\mathrm{~S}$ & $S$ & 0 \\
\hline BL_16 & Brilhoso & $\mathrm{PE}$ & M & $\mathrm{R}$ & $\mathrm{R}$ & $\mathrm{R}$ & 100 \\
\hline BL_19 & IPA 1 & $\mathrm{PE}$ & $M$ & $\mathrm{R}$ & $\mathrm{R}$ & $\mathrm{R}$ & 100 \\
\hline BL_24 & Mulatinho de Cacho & PB & $M$ & $\mathrm{R}$ & $\mathrm{R}$ & $\mathrm{R}$ & 100 \\
\hline BL_30 & Flor Azul & $\mathrm{PE}$ & $M$ & $\mathrm{R}$ & $\mathrm{R}$ & $\mathrm{R}$ & 100 \\
\hline BL_31 & Bico de ouro & $\mathrm{PE}$ & M & $S$ & $\mathrm{R}$ & $\mathrm{R}$ & 66.67 \\
\hline BL_34 & Laje & PB & $M$ & $\mathrm{R}$ & $\mathrm{R}$ & $\mathrm{R}$ & 100 \\
\hline BL_35 & Caiaminha & $\mathrm{PE}$ & $M$ & $\mathrm{R}$ & $\mathrm{S}$ & $S$ & 33.33 \\
\hline BL_50 & CLPE17 & $\mathrm{PE}$ & $M$ & $\mathrm{R}$ & $\mathrm{R}$ & $\mathrm{R}$ & 100 \\
\hline BL_66 & CLPE40 & $\mathrm{PE}$ & $M$ & $\mathrm{R}$ & $\mathrm{R}$ & $\mathrm{R}$ & 100 \\
\hline BL_67 & CLPE41 & $\mathrm{PE}$ & $M$ & $\mathrm{R}$ & $\mathrm{R}$ & $\mathrm{R}$ & 100 \\
\hline BL_69 & CLPE44 & $\mathrm{PE}$ & $M$ & $\mathrm{R}$ & $\mathrm{R}$ & $\mathrm{R}$ & 100 \\
\hline BL_70 & CLPE45 & $\mathrm{PE}$ & $M$ & $\mathrm{R}$ & $\mathrm{R}$ & $\mathrm{R}$ & 100 \\
\hline BL_71 & CLPE47 & $\mathrm{PE}$ & $M$ & $S$ & $\mathrm{R}$ & $S$ & 33.33 \\
\hline BL_76 & CLPE55 & $\mathrm{PE}$ & $M$ & $\mathrm{R}$ & $\mathrm{R}$ & $\mathrm{R}$ & 100 \\
\hline BL_80 & CLPE61 & $\mathrm{PE}$ & M & $S$ & $\mathrm{~S}$ & $S$ & 0 \\
\hline BL_81 & CLPE63 & $\mathrm{PE}$ & $M$ & $S$ & $S$ & $S$ & 0 \\
\hline BL_82 & CLPE65 & $\mathrm{PE}$ & $M$ & $S$ & $\mathrm{~S}$ & $S$ & 0 \\
\hline BL_83 & CLPE66 & $\mathrm{PE}$ & M & $S$ & $\mathrm{~S}$ & $S$ & 0 \\
\hline BL_84 & CLPE67 & $\mathrm{PE}$ & $M$ & $S$ & $\mathrm{~S}$ & $S$ & 0 \\
\hline BL_85 & CLPE68 & $\mathrm{PE}$ & M & $\mathrm{R}$ & $\mathrm{R}$ & $\mathrm{R}$ & 100 \\
\hline BL_86 & CLPE69 & $\mathrm{PE}$ & M & $S$ & $\mathrm{~S}$ & $S$ & 0 \\
\hline BL_87 & CLPE74 & $\mathrm{PE}$ & $\mathrm{M}$ & $\mathrm{R}$ & $\mathrm{R}$ & $\mathrm{R}$ & 100 \\
\hline BL_88 & CLPE75 & $\mathrm{PE}$ & M & $S$ & $\mathrm{~S}$ & S & 0 \\
\hline BL_90 & CLPE80 & $\mathrm{PE}$ & M & $\mathrm{R}$ & $\mathrm{R}$ & S & 66.67 \\
\hline BL_91 & CLPE81 & $\mathrm{PE}$ & $M$ & $\mathrm{R}$ & $\mathrm{R}$ & $S$ & 66.67 \\
\hline
\end{tabular}




\begin{tabular}{|c|c|c|c|c|c|c|c|}
\hline BL_92 & CLPE87 & $\mathrm{PE}$ & $\mathrm{M}$ & $\mathrm{R}$ & $S$ & $S$ & 33.33 \\
\hline BL_95 & CLPE90 & $\mathrm{PE}$ & M & $S$ & $S$ & $S$ & 0 \\
\hline BL_96 & CLPE91 & $\mathrm{PE}$ & M & $S$ & $S$ & $S$ & 0 \\
\hline BL_99 & CLPE92 & $\mathrm{PE}$ & $\mathrm{M}$ & $S$ & $S$ & $S$ & 0 \\
\hline BL_100 & CLPE89 & $\mathrm{PE}$ & M & $\mathrm{R}$ & $S$ & $S$ & 33.3 \\
\hline BL_102 & CLPE94 & $\mathrm{PE}$ & M & $\mathrm{R}$ & $S$ & $S$ & 33.3 \\
\hline BL_103 & CLPE96 & $\mathrm{PE}$ & M & $\mathrm{R}$ & $S$ & $S$ & 33.3 \\
\hline BL_104 & CLPE86 & $\mathrm{PE}$ & M & $S$ & $\mathrm{R}$ & S & 33.3 \\
\hline BL_105 & CLPE83 & $\mathrm{PE}$ & M & $S$ & $S$ & $S$ & 0 \\
\hline BL_106 & BG-4 & MT & M & S & $S$ & $S$ & 0 \\
\hline BL_107 & BG-9 & MT & M & S & $S$ & $\mathrm{R}$ & 33.33 \\
\hline BL_108 & BG-13 & MT & M & S & $S$ & $\mathrm{R}$ & 33.33 \\
\hline BL_109 & BG-17 & MT & M & $S$ & $S$ & $S$ & 0 \\
\hline BL_110 & BG-18 & MT & M & $S$ & $\mathrm{R}$ & $S$ & 33.33 \\
\hline BL_111 & BG-23 & MT & $\mathrm{M}$ & $S$ & $S$ & $S$ & 0 \\
\hline BL_174 & Juriti & $\mathrm{PR}$ & M & $\mathrm{R}$ & $\mathrm{R}$ & $S$ & 66.67 \\
\hline BL_177 & Awauna & PR & M & $\mathrm{R}$ & $\mathrm{R}$ & $\mathrm{R}$ & 100 \\
\hline BL_181 & MT 50G & MT & $\mathrm{M}$ & $\mathrm{R}$ & $\mathrm{R}$ & $\mathrm{R}$ & 100 \\
\hline BL_183 & MT 55 & MT & M & $\mathrm{R}$ & $\mathrm{R}$ & $\mathrm{R}$ & 100 \\
\hline BL_184 & MT 57G1 & MT & M & $\mathrm{R}$ & $S$ & $\mathrm{R}$ & 66.67 \\
\hline BL_186 & MT 62 & MT & M & $\mathrm{S}$ & $S$ & $\mathrm{~S}$ & 0 \\
\hline BL_187 & MT 73G1 & MT & M & S & $\mathrm{R}$ & $\mathrm{R}$ & 66.67 \\
\hline BL_189 & MT 79 & MT & $\mathrm{M}$ & $\mathrm{R}$ & $\mathrm{R}$ & $\mathrm{R}$ & 100 \\
\hline BL_216 & CLPE32 & PE & M & $\mathrm{R}$ & $\mathrm{R}$ & $\mathrm{R}$ & 100 \\
\hline BL_225 & Sempre Assim & $\mathrm{PE}$ & M & $\mathrm{R}$ & $\mathrm{R}$ & $\mathrm{R}$ & 100 \\
\hline BL_226 & CLPE3 & $\mathrm{PE}$ & $\mathrm{M}$ & $S$ & $S$ & $\mathrm{R}$ & 33.33 \\
\hline BL_227 & CLPE4 & $\mathrm{PE}$ & M & S & $S$ & $S$ & 0 \\
\hline BL_228 & CLPE8 & $\mathrm{PE}$ & M & $S$ & $S$ & $S$ & 0 \\
\hline BL_229 & CLPE10 & $\mathrm{PE}$ & $\mathrm{M}$ & $S$ & $S$ & $S$ & 0 \\
\hline BL_230 & CLPE11 & $\mathrm{PE}$ & M & S & S & $S$ & 0 \\
\hline BL_234 & CLPE21 & $\mathrm{PE}$ & M & S & S & $\mathrm{R}$ & 33.33 \\
\hline \multicolumn{3}{|c|}{ Pathogenicity Index (\%) } & & 50.00 & 51.67 & 53.33 & \\
\hline
\end{tabular}

${ }^{1} \mathrm{PE}=$ Pernambuco, $\mathrm{PB}=$ Paraíba, MT= Mato Grosso, PR= Paraná.

\subsection{GBS-based genome-wide association analyses}

Association mapping of the 89 common bean accessions with $C$. lindemuthianum race 2 resulted in the identification of three SNPs on chromosome Pv04, one SNP on Pv06, and five on Pv11. The relationship of the positions of the anthracnose resistance loci found in the present study and the loci already described in the literature are illustrated in Figure 3, using the common bean reference genome version 2.1. GWAS for anthracnose race 9 resistance resulted in the identification of three SNPs on chromosome Pv04. Association mapping of race 1545 resistance allowed the identification of one SNP on chromosome Pv03 and five SNPs on Pv05 (Table 4; Figures 4, 5, and 6). One hundred and 
eleven model genes were found in the $100 \mathrm{~kb}$ region upstream and downstream of the physical position of the SNPs associated with races 2, 9 and 1545 resistance in the common bean reference genome v1.0. Out of them, 20 were annotated with any function related to disease response and, thus, are candidate genes for anthracnose resistance (Table 5).

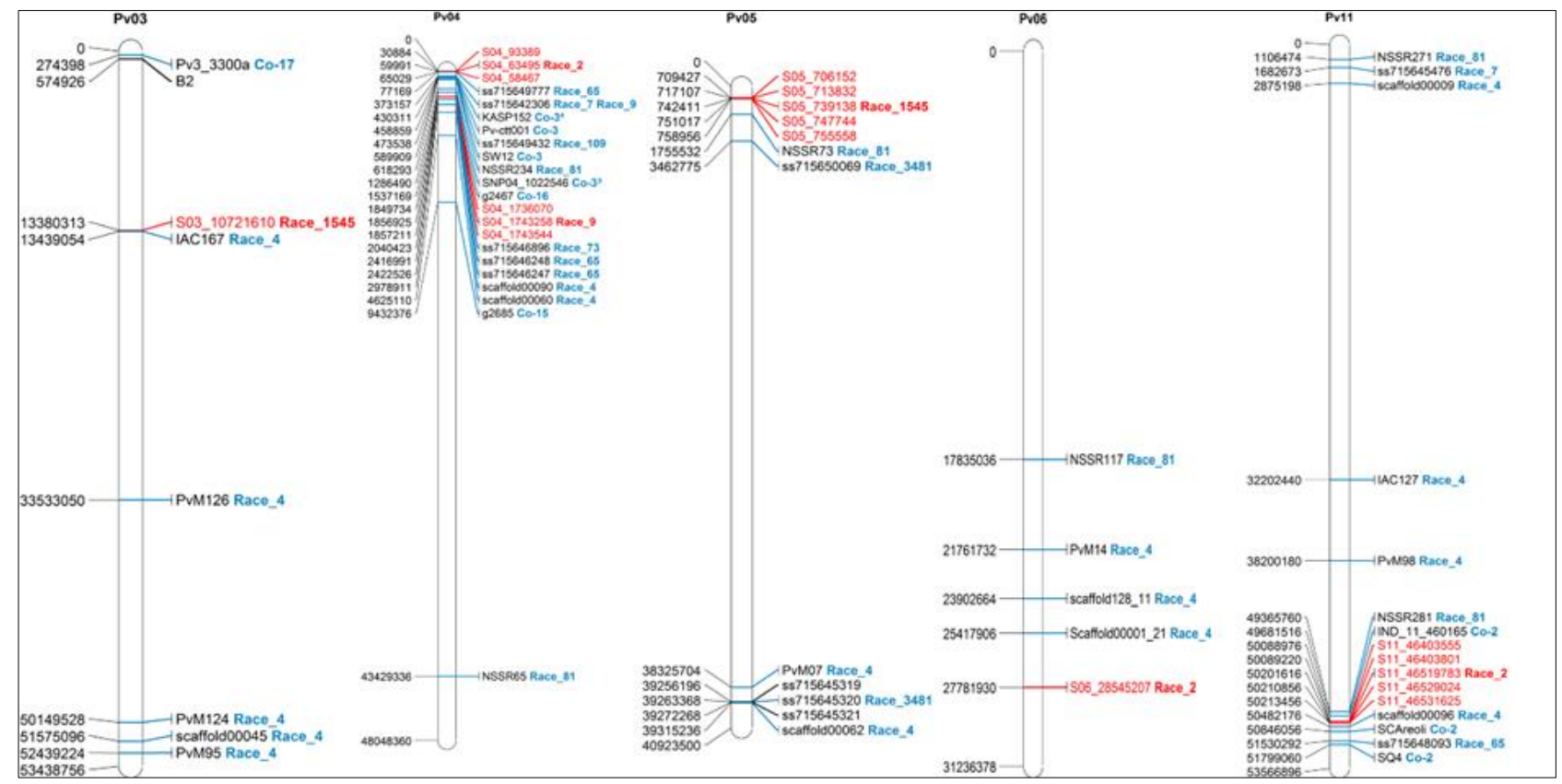

Figure 3 Common bean chromosomes Pv03, Pv04, Pv05, Pv06, and Pv11 showing anthracnose resistance loci found in this study colored in red, loci already described in the literature colored in blue, molecular markers tagging the resistance loci colored in black with physical position based on the Phaseolus vulgaris reference genome v2.1.

Table 4 Associations between SNP and anthracnose resistance for races 2, 9, and 1545 of $C$. lindemuthianum determined by mixed linear models (MLM)

\begin{tabular}{|c|l|c|c|c|c|}
\hline Race & SNP & Pv $^{1}$ & Position $^{2}$ & p-value & SNP R \\
\hline 2 & S04_58467 & $\mathbf{4}^{\mathbf{4}}$ \\
\hline 2 & S04_63495 & 04 & 58,467 & $3.84 \mathrm{E}-05$ & 21.81 \\
\hline 2 & S04_93389 & 04 & 63,495 & $9.12 \mathrm{E}-06$ & 27.16 \\
\hline 2 & S06_28545207 & 06 & $28,545,207$ & $4.89 \mathrm{E}-04$ & 18.64 \\
\hline 2 & S11_46403555 & 11 & $46,403,555$ & $2.11 \mathrm{E}-04$ & 17.28 \\
\hline 2 & S11_46403801 & 11 & $46,403,801$ & $6.75 \mathrm{E}-04$ & 14.34 \\
\hline 2 & S11_46519783 & 11 & $46,519,783$ & $2.21 \mathrm{E}-04$ & 17.23 \\
\hline 2 & S11_46529024 & 11 & $46,529,024$ & $8.74 \mathrm{E}-04$ & 14.32 \\
\hline 2 & S11_46531625 & 11 & $46,531,625$ & $9.73 \mathrm{E}-04$ & 17.45 \\
\hline 9 & S04_1736070 & 04 & $1,736,070$ & $6.21 \mathrm{E}-04$ & 15.18 \\
\hline 9 & S04_1743258 & 04 & $1,743,258$ & $6.21 \mathrm{E}-04$ & 15.18 \\
\hline 9 & S04_1743544 & 04 & $1,743,544$ & $6.21 \mathrm{E}-04$ & 15.18 \\
\hline 1545 & S03_13038972 & 03 & $13,038,972$ & $6.18 \mathrm{E}-04$ & 15.62 \\
\hline 1545 & S05_706152 & 05 & 706,152 & $6.88 \mathrm{E}-04$ & 14.87 \\
\hline 1545 & S05_713832 & 05 & 713,832 & $6.88 \mathrm{E}-04$ & 14.87 \\
\hline 1545 & S05_739138 & 05 & 739,138 & $6.88 \mathrm{E}-04$ & 14.87 \\
\hline 1545 & S05_747744 & 05 & 747,744 & $6.88 \mathrm{E}-04$ & 14.87 \\
\hline 1545 & S05_755558 & 05 & 755,558 & $6.88 \mathrm{E}-04$ & 14.87 \\
\hline
\end{tabular}


Table 5 Candidate genes for ANT races 2, 9, and 1545 resistance within $100 \mathrm{~Kb}$ region at either side of the significant SNP or interval in reference genome v1.0 with function annotation related to disease response

\begin{tabular}{|c|c|c|}
\hline Race & Candidate gene & Functional annotation \\
\hline 2 & Phvul.004G000500 & Sphingosine kinase \\
\hline 2 & Phvul.004G000800 & Pyruvate kinase-related \\
\hline 2 & Phvul.004G001200 & Copper transport protein ATOX1-related \\
\hline 2 & Phvul.006G174100 & Receptor like protein 55 \\
\hline 2 & Phvul.006G174200 & $\begin{array}{l}\text { PPR repeat (PPR) // PPR repeat family (PPR_2) // DYW family of } \\
\text { nucleic acid deaminases }\end{array}$ \\
\hline 2 & Phvul.006G174400 & $\begin{array}{l}\text { Protein kinase domain (Pkinase) // Leucine rich repeat N-terminal } \\
\text { domain (LRRNT_2) }\end{array}$ \\
\hline 2 & Phvul.006G174700 & Leucine-rich repeat receptor-like protein kinase \\
\hline 2 & Phvul.006G174800 & Cbl-interacting serine/threonine-protein kinase 12-related \\
\hline 2 & Phvul.006G174900 & Cbl-interacting serine/threonine-protein kinase 2 \\
\hline 2 & Phvul.006G175100 & LRR receptor-like serine/threonine-protein kinase mrh1-related \\
\hline 2 & Phvul.011G186900 & Serine/threonine-protein kinase cg17528 \\
\hline 2 & Phvul.011G187400 & Ethylene-responsive transcription factor wri1 \\
\hline 9 & Phvul.004G016300 & F-box domain (F-box) // Leucine Rich Repeat (LRR_2) // FBD (FBD) \\
\hline 9 & Phvul.004G016400 & F-box domain (F-box) // Leucine Rich Repeat (LRR_2) // FBD (FBD) \\
\hline 9 & Phvul.004G016600 & F-box domain (F-box) // Leucine Rich Repeat (LRR_2) // FBD (FBD) \\
\hline 9 & Phvul.004G016900 & Serine-threonine protein kinase \\
\hline 1545 & Phvul.003G080900 & Wall-associated receptor kinase galacturonan-binding \\
\hline 1545 & Phvul.005G008100 & Ppr repeat (ppr) // ppr repeat family (ppr_2) \\
\hline 1545 & Phvul.005G008500 & F-box and leucine-rich repeat protein 2/20 (fbxl2_20) \\
\hline 1545 & Phvul.005G009000 & Ceramide kinase / Acylsphingosine kinase \\
\hline
\end{tabular}

\subsubsection{Genome-wide association for race 2}

Association mapping of the 89 common bean accessions with $C$. lindemuthianum race 2 resulted in the identification of potential QTLs on chromosomes Pv04, Pv06, and Pv11. The significance region of the QTL on Pv04 was located in a $34,922 \mathrm{bp}$-interval starting at 58,467 bp and ending at 93,389 bp in the top region of chromosome Pv04. Three SNPs in this interval - S04_58467, S04_63495, and S04_93389 - were significantly associated with the resistance and explained, respectively, $22 \%, 27 \%$ and $19 \%$ of the phenotypic variation (Table 4, Figure 4).

Anthracnose resistance genes have been mapped in this same region at the beginning of chromosome Pv04 in several distinct cultivars. This includes mainly the ANT resistance locus $\mathrm{Co}-3$ and its allelic series $\mathrm{Co}-3^{2}, \mathrm{Co}-3^{3}, \mathrm{Co}-3^{4}$, and $\mathrm{Co}-3^{5}$ $[32,33,34,35,36]$. In addition, Co-y of the Andean cultivar Jalo EEP558 has been mapped at the same location as Co-9 (later renamed $\mathrm{Co}^{-3^{3}}$ ) from the Mesoamerican breeding line BAT93 [35].

The BAT93 resistance gene against race $73\left(\mathrm{Co}_{-3}{ }^{B}\right)$ is flanked by markers SNP04_027 (552,092 bp) and $254-\mathrm{G} 15$ $(1,618,118 \mathrm{bp})$. However, the resistance against race $38\left(\mathrm{Co}-3^{B}\right)$ was fine-mapped in two regions; the first is flanked by SNPs SNP04_1022546 (1,286,490 bp) and SNP04_1308175 (1,419,089 bp), and the second region is delimited by markers IND04_10936 (1,908,814 bp) and SNP04_1231633 (2,047,754 bp) [37]. 


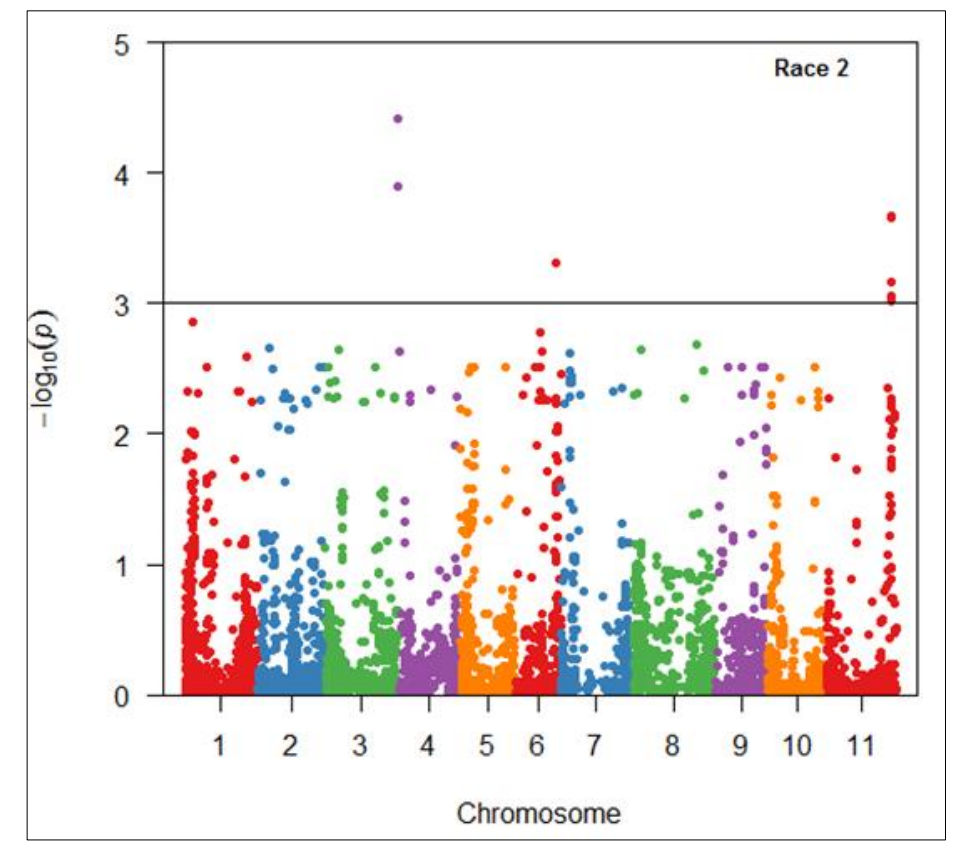

Figure 4 Manhattan plot showing SNPs and $p$-values from GWAS for anthracnose resistance against race 2. Significance threshold $\mathrm{p}<0.001$

The resistance gene $\mathrm{Co}-3^{4}$ in the Ouro Negro cultivar was first mapped at the position 3,356,300 bp of Pv04, linked at $0.0 \mathrm{cM}$ to the STS marker g2303 [36]. Later, Valentini et al. (2017) [38], studying co-segregation analysis for rust and anthracnose diseases in the population Ouro Negro $\times$ Rudá, mapped Co-34 at a distance of 0.1 and $0.3 \mathrm{cM}$ from KASP152 $(487,659 \mathrm{bp})$ and KASP153 (575,006 bp), respectively. Additional resistance alleles were found in the Co-3 cluster in the Andean cultivars Widusa, Kaboon, Xana, and MDRK, as well as in the Mesoamerican A252 line [5, 39, 40, 41, 42].

The Co-16 resistance gene present in the cultivar Crioulo 159 mapped in a different position from Co-3 on Pv04 at $1,428,279 \mathrm{bp}$ linked to the marker g2467 at $5 \mathrm{cM}$ [43]. Moreover, resistance gene Co-15 present in the cultivar Corinthiano was mapped on chromosome Pv04 linked at 5.6 cM to the marker g2686 located at 9,078,200 bp [44].

GWAS for anthracnose resistance using different races also identified regions in Pv04 conferring resistance. Zuiderveen et al. (2016) [12] found associations on Pv04 for resistance to races 7 and 109. The SNP ss715642306 at the position 447,165 bp was associated with race 7 . Resistance to race 109 was associated with the SNP ss715649432 located at $532,194 \mathrm{bp}$. The authors suggested that this resistance could be associated with the Co-3 locus. Perseguini et al. (2016) [13] observed associations with resistance to race 4 on Pv04. The associated markers were scaffold00090_802505 and scaffold00060_874577 located at 2,701,631 bp and 4,395,872 bp, respectively. Wu et al. (2017) [14] found two SSR markers associated with race 81 resistance on Pv04: NSS234 marker located at 673,367 bp and NSSR65 marker located at $41,368,421 \mathrm{bp}$. The first marker may be in the same genomic region of Co-3. Vidigal Filho et al. (2020) [16] found associations on Pv04 for resistance to races 9, 65 and 73. The SNP ss715649432 at the position 532,254 bp was associated with race 9. Resistance to race 65 was associated with the SNP ss715646248 located at 2,142,289 bp. The SNP ss715646896 at the position $1,224,240$ bp was associated with race 73 . Through linkage and genome-wide association analyses different loci controlling resistance to different isolates of race 65 of Colletotrichum lindemuthianum were identified by Costa et al. (2021) [17]. In chromosome Pv04 the identified SNPs are located from 46,027 bp (ss715649777) until 2,147,821 bp (ss715646247). Therefore, the region identified in the present study for resistance to race 2 corroborates the region identified using different isolates of race 65 by Costa et al. (2021) [17].

In the reference genome, 16 candidate genes are located close to the region from the SNPs S04_58467 and S04_93389, associated with race 2 resistance in this study. Three of these genes encode proteins with functional annotation potentially related to disease reaction (Table 5). Among them, Phvul.004G000500 and Phvul.004G000800 encode kinases, which act as pattern-recognition receptors by recognizing pathogen-associated molecular patterns (PAMPs) $[45,46]$ (Jones and Dangl, 2006; Zipfel, 2014). Also, Phvul.004G001200 encodes a Copper transport protein ATOX1related protein. The ATOX1 protein is a candidate gene for resistance to soybean mosaic virus strain SC5 and was differentially expressed in resistant and susceptible cultivars under infection [47]. Previous studies in Arabidopsis revealed upregulation at the transcription level of ATOX1 encoding-gene in response to cytokinin that acts as key 
signaling molecule inducing resistance actions against pathogen infection [48]. Thus, the beginning of Pv04 contains a large cluster or multiple clusters of phenotypic resistance genes. It may not be surprising, therefore, that more than 40 nucleotide-binding leucine-rich repeat (NBS-LRR) encoding-genes and other genes involved in host-pathogen interactions have been identified in this region [26].

The SNP S06_28545207 was significantly associated with race 2 resistance on chromosome Pv06. In the reference genome v1.0, this SNP is located at 28,545,207 bp and explains $19 \%$ of the phenotypic variation (Table 4, Figure 4). Other GWAS for anthracnose resistance found associations with resistance to ANT on Pv06. Perseguini et al. (2016) [13] identified one SSR and four SNP markers associated with resistance to race 4 on Pv06, namely: PvM14 (22,466,054 bp), scaffold00128_112577 (24,577,146 bp), scaffold00128_197955 (24,659,226 bp), scaffold00001_2118513 (26,202,771 bp), and scaffold00001_1947432 (26,390,866 bp). Also, Wu et al. (2017) found one marker associated with resistance against race 81 on Pv06 (NSSR117, at 18,546,221 bp).

In the common bean reference genome, 23 candidate genes are found in the $100 \mathrm{~kb}$ region upstream and downstream of the physical position of the SNP S06_28545207. Seven genes encode proteins related to disease response (Table 5). The gene model Phvul.006G174100 encodes a Receptor-like protein (RLP) that is a pattern recognition receptor (PRR) that mediate pathogen-associated molecular pattern (PAMP)-triggered immunity (PTI) to allow recognition of a broad range of pathogens [49]. Pentatricopeptide repeats (PPRs) were also found in this study (Phvul.006G174200). PPRs are involved in plant defense; they translocate to chloroplast and mitochondria to perform post-transcriptional processing such as RNA editing, splicing and translation modification [50]. The gene models Phvul.006G174400, Phvul.006G174700, and Phvul.006G175100 encode leucine-rich repeat receptor-like protein kinase (LRR-RLK) that is known to actively participate in the regulation of the growth, development, signal transduction, immunity, and stress responses of plants [51]. This study also found the model genes Phvul.006G174800 and Phvul.006G174900 that encode Calcium-dependent protein kinases (CDPKs). They act in hormone and stress signaling and pathogen response [52, 53].

Five SNPs were found significantly associated with resistance to race 2 on chromosome Pv11. The SNPs S11_46403555, S11_46403801, S11_46519783, S11_46529024, and S11_46531625 explained, respectively, $17 \%$ each of the phenotypic variation (Table 4, Figure 4). These SNPs were located at the end of the chromosome in a 128,070 bp interval, from 46,403,555 bp to $46,531,625$ bp. The Co-2 locus, a major anthracnose resistance gene reported in the Mesoamerican differential cultivar Cornell 49242 was mapped in the same region of chromosome, linked to the markers SCAreoli located at 47,134,388 bp and SQ4 located at 48,063,823 bp [5].

A 252 cultivar carries a resistance gene against race 31 linked to the marker SCAreoli at $14.0 \mathrm{cM}$ on chromosome Pv11 [42]. A resistance locus was mapped in the $\mathrm{AB} 136$ cultivar at the end of Pv11, in the same region of Co-2, between markers IND11_460165 (46,0Mb) and IND11_477711 (47,7Mb) [40].

Other GWAS for races 4, 7, and 81 found associations with resistance to ANT located on chromosome Pv11. Three SNPs and two SSR markers were found associated with resistance against race 4: Scaffold00009_1366067 (2,695,661 bp), scaffold00009_825782 (3,270,820 pb), IAC127 (28,334,236 bp), PvM98 (38,007,419 bp) and Scaffold00096_204246 $(46,792,860 \mathrm{bp})$. The latter markers cover part of the $\mathrm{Co}-2$ region, the other markers are located in other regions of Pv11 [13]. The SNP ss715645476 (1.69 Mb) was found associated with resistance to race 7 on Pv11 and seems to be a distinct resistance gene, which may play a complementary role to the resistance gene found for race 7 on Pv04 [12]. For race 81, two clusters of resistance genes were found associated with ANT on Pv11. The first cluster is located at 1,111,792 bp (relatively close to the SNP found for race 7), while the second cluster is located at 45,753,810 bp, and is composed of 34 NBS-LRR genes from Phvul.011G181400 to Phvul.011G198400 [14] and might be located in the Co-2 cluster. Costa et al. (2021) [17] identified the marker ss715648093 located at 47,800,050 associated to the resistance of the isolate Cl1532 of race 65 in Pv11, also in the Co-2 cluster.

In the reference genome, 21 gene models are found between SNPs S11_46403555 and S11_46531625, and the 100kb boundaries of these SNPs. Two genes encode proteins that could be related to disease response (Table 5). The Phvul.011G186900 gene model encodes a serine/threonine-protein kinase cg17528. Moreover, Phvul.011G187400 encodes an ethylene-responsive transcription factor wri1, which is known to be involved in the regulation of gene expression by stress and in signal transduction pathways. Sessa et al. (1995) [54] stated that pathogenesis-related protein activation at transcriptional level can happen by the plant hormone ethylene. The accumulation of pathogenesisrelated protein also can occur in response to ethylene in the presence of calcium. 


\subsubsection{Genome-wide association for race 9}

Genome-wide association for race 9 resistance resulted in the identification of three SNPs on chromosome Pv04 accounting for $15 \%$ of the total phenotypic variation, for each marker (Table 4, Figure 5). The SNPs S04_1736070, S04_1743258, and S04_1743544 are positioned in the beginning of the chromosome in a genomic region encompassing $7,474 \mathrm{bp}$ interval from $1,736,070 \mathrm{bp}$ to $1,743,544 \mathrm{bp}$. This region has been mapped for disease resistance in different bean cultivars corresponding to the $\mathrm{Co}-3$ cluster. The importance of Pv04 in conferring resistance to anthracnose has been discussed and addressed in the previous section of this study.

In the reference genome, 16 gene models are found close to the three SNPs. Three of them, Phvul.004G016300, Phvul.004G016400, and Phvul.004G016600, encode F-box domain (F-box) // Leucine Rich Repeat (LRR_2) // FBD (FBD) (Table 5). The LRR domain provides a versatile structural framework for the formation of protein-protein interactions. This protein belongs to the NBS-LRR gene family, which has been recruited to detect intracellular interference by diverse pathogen effectors and initiate effector-triggered immunity (ETI) [55, 56]. Phvul.004G016900 encodes a serinethreonine protein kinase, a type of protein known to act in the plant immune system. Kinases operate as patternrecognition receptors (PRRs) that recognize hormones, PAMPs, and pathogens effectors, and activate immune responses [57].

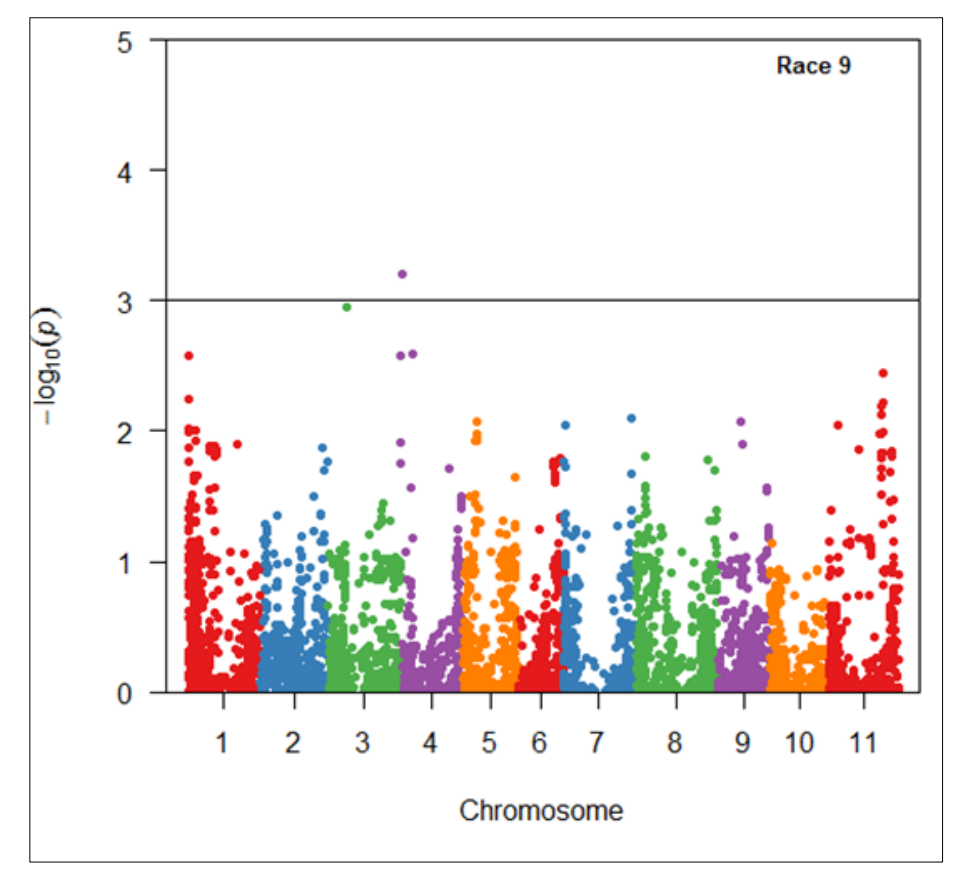

Figure 5 Manhattan plot showing SNPs, and $p$-values from GWAS for anthracnose resistance against race 9. Significance threshold $\mathrm{p}<0.001$

\subsubsection{Genome-wide association for race 1545}

Genome-wide association analyses for race 1545 resistance led to the identification of one SNP on chromosome Pv03 and five SNPs on Pv05 (Table 4, Figure 6). The SNP S03_13038972 located at 13,038,972 bp on Pv03 explained $15 \%$ of the phenotypic variation. Currently, there are two resistance genes mapped on chromosome Pv03. The first mapped gene was $\mathrm{Co}-13$, reported in the Andean Jalo Listras Pretas landrace and linked to marker OV20680 [58]. Remarkably, the $\mathrm{Co}-13$ gene also confers resistance to race 1545 [59]. The second gene is Co-17, which was described in the Mesoamerican SEL 1308 cultivar [6].

Previous GWAS for race 4 also identified six markers associated with resistance on Pv03. The markers and their respective positions were: IAC167 (13,097,396 bp), PVEST236 (32,935,150 bp), PvM126 (32,935,183 bp), PvM124 $(48,995,346 \mathrm{bp})$, scaffold00045 (50,422,102 bp), and PvM95 (51,280,966 bp) [13]. The region found associated with race 1545 in this work is located at the position $13,038,972 \mathrm{bp}$, which is $58 \mathrm{~kb}$ distant from the marker IAC167 $(13,097,396 \mathrm{bp})$ associated with race 4 resistance. In the reference genome v1.0, 10 model genes are found close to SNP S03_13038972 on Pv03. Only the gene Phvul.003G080900 encodes a protein kinase, which acts in defense response. 


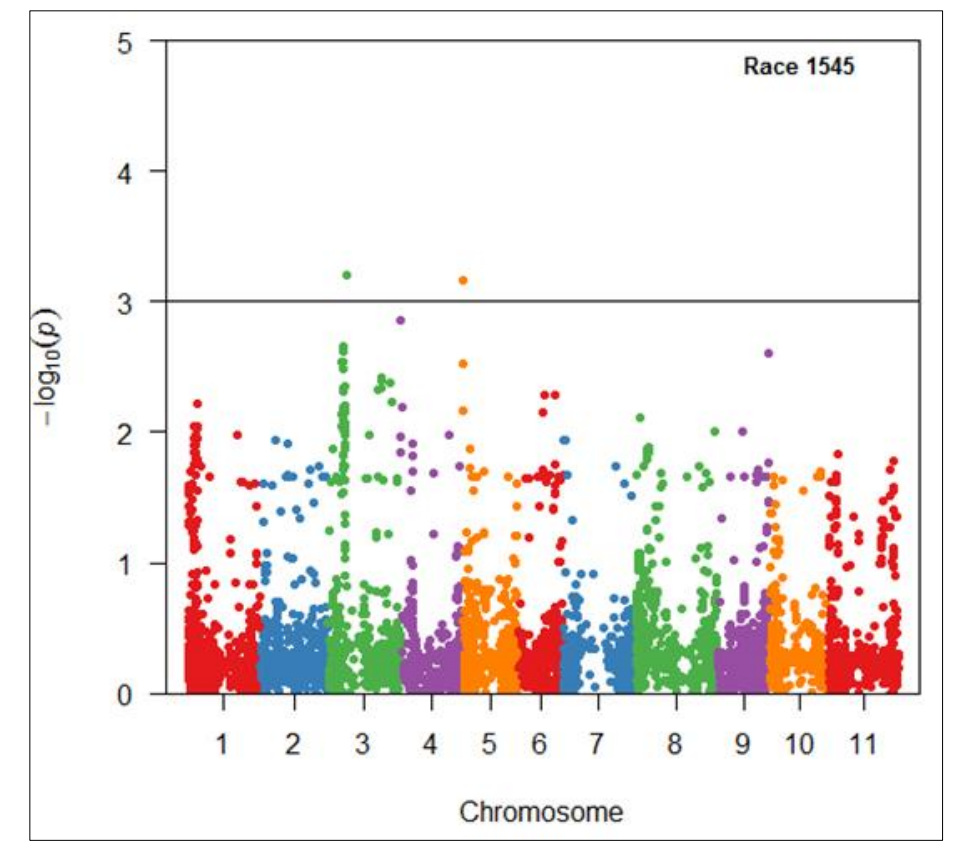

Figure 6 Manhattan plot showing SNPs, and $p$-values from GWAS for anthracnose resistance against race 1545. Significance threshold $p<0.001$.

The five SNPs identified on Pv05 - S05_706152, S05_713832, S05_739138, S05_747744, and S05_755558 (Table 4, Figure 6) - were located in a genomic region of 49,406 bp at the beginning of the chromosome, between 706,152 bp and 755,558 bp. Each SNP explained $15 \%$ of the phenotypic variation. Previous GWAS for race 4 identified two markers associated with the resistance on chromosome Pv05: PvM07 (38,024,011 bp) and Scaffold00062 (39,080,673 bp) [13]. Vidigal Filho et al. (2020) [16] identified three SNPs associated with race 3481 in Pv05: ss715645319 (39,020,188 bp), ss715645320 (39,027,362 bp) and ss715645321 (39,035,656 bp). Through the same type of study, resistance against race 81 was associated with marker NSSR73 at the position of 1,746,532 bp on Pv05 [14]. Costa et al. (2021) [17] identified the marker ss715650069 located at 3,452,977 bp associated to the resistance of the isolate $\mathrm{Cl} 1532$ of race 65 in Pv05. Therefore, the resistance loci against race 1545 found in this study were located in a different position from the region found for races 4 and 3481. Moreover, it is located in a distance of $1.0 \mathrm{Mb}$ and 2,7 $\mathrm{Mb}$ from the genomic region identified for resistance to race 81 and 65 , respectively.

A total of 25 genes were found close to the SNPs associated with resistance to race 1545 on chromosome Pv05. Three genes encode proteins that might function in resistance. Gene Phvul.005G008100 encodes a PPR (pentatricopeptide) repeat, which is a type of protein that is modular RNA-binding and mediates gene expression in organelles and nucleus [60]. Gene Phvul.005G008500 encodes an F-box and leucine-rich repeat protein 2/20. F-box proteins regulate various cellular processes such as cell cycle transition, transcriptional regulation, and signal transduction, and LRR domain are involved in protein-protein interaction [61]. Finally, gene Phvul.005G009000 encodes a protein kinase (Table 5).

In summary, the results show that both Andean and Mesoamerican bean accessions evaluated in this study are genetically distinct in response to races 2, 9, and 1545 of $C$. lindemuthianum. Some of this genetic material could be valuable in future bean breeding programs as new sources of resistance to anthracnose. Genome-wide association for C. lindemuthianum race 2 resulted in the identification of SNPs on chromosomes 4, 6, and 11 associated with resistance to ANT. The SNPs found on Pv04 and Pv11 may be located in the Co-3 and Co-2 clusters, respectively. GWAS for race 9 showed that SNPs at the beginning of Pv04 are associated with resistance to ANT. These SNPs are located close to the Co-3 cluster, a genomic region where other ANT resistance genes have been mapped previously. Genome-wide association against race 1545 was found in previously unreported genomic regions on Pv03 and Pv05.

\section{Conclusion}

The present study delivers valuable results as we identified new Andean and Mesoamerican common bean anthracnose resistance sources and 18 SNPs significantly associated with resistance to races 2, 9, and 1545 . Furthermore, we found 20 candidate genes for ANT resistance that encoded proteins with functions previously related to disease resistance. These proteins are kinases, leucine-rich repeats, receptor- like protein, copper transport protein, pentatricopeptide 
repeats, calcium-dependent protein kinases, and ethylene-responsive transcription factor. The genomic regions associated to ANT resistance found in this study should be validated for further use in marker assisted selection and gene pyramiding. Together with new sources of ANT resistance our findings show promise for further crop improvement.

\section{Compliance with ethical standards}

\section{Acknowledgments}

This research was financially supported by the National Council for Scientific and Technological Development (CNPq). M. Vaz Bisneta, G. Valentini, L. R. R. Lima, J. were supported by a Scholarship from CAPES, Brasilia. C.F. Elias was supported by a scholarship from CNPq, Brasilia. M.C. Gonçalves-Vidigal and P. S. Vidigal Filho are grateful for grants from CNPq. A.A. was supported by Agriculture and Food Research Initiative (AFRI) Competitive Grant No. 2013-6701321224 from the USDA National Institute of Food and Agriculture to P.G.

\section{Disclosure of conflict of interest}

The authors declare that No conflict of interest.

\section{References}

[1] Thompson SV, Winham DM, Hutchins AM. Bean and rice meals reduce postprandial glycemic response in adults with type 2 diabetes: a cross-over study. Nutr J. 2012; 11: 23.

[2] Broughton WJ, Hernandez G, Blair M, Beebe S, Gepts P, Vanderleyden J. Beans (Phaseolus spp.) - model food legumes. Plant Soil. 2003; 252: 55-128.

[3] Singh SP, Schwartz HF. Breeding common bean for resistance to diseases: a review. Crop Sci. 2010; 50: 21992223.

[4] Padder BA, Sharma PN, Awale HE, Kelly JD. Colletotrichum lindemuthianum, the causal agent of bean anthracnose. J Plant Pathol. 2017; 99: 317-330.

[5] Campa A, Rodríguez-Suárez C, Giraldez R, Ferreira JJ. Genetic analysis of the response to eleven Colletotrichum lindemuthianum races in a RIL population of common bean (Phaseolus vulgaris L.). BMC Plant Biol. $2014 ; 14: 115$.

[6] Trabanco N, Campa A, Ferreira JJ. Identification of a new chromosomal region involved in the genetic control of resistance to anthracnose in common bean. The plant genome. 2015; 8: 1-11.

[7] Meziadi C, Richard MMS, Derquennes A, Thareau V, Blanchet S, Gratias A, Pflieger S, Geffroy V. Development of molecular markers linked to disease resistance genes in common bean based on whole genome sequence. Plant Sci. 2016; 242: 351-357.

[8] Burghardt LT, Young, ND, Tiffin P. A guide to genome-wide association mapping in plants. Curr Protoc Plant Biol. 2017; 2: 22-38.

[9] Rafalski JA. Association genetics in crop improvement. Curr Opin Plant Biol. 2010; 13 : 174 -180.

[10] Brachi B, Morris G, Borevitz JO. Genome-wide association studies in plants: the missing heritability is in the field. Genome Biol. 2011; 12: 232.

[11] Huang X, Han B. Natural variations and genome-wide association studies in crop plants. Annu Rev Plant Biol. 2014; 65: 531-51.

[12] Zuiderveen GH, Padder BA, Kamfwa K, Song K, Kelly JD. Genome-wide association study of anthracnose resistance in Andean beans (Phaseolus vulgaris). PLoS ONE. 2016; 11: e0156391.

[13] Perseguini JMKC, Oblessuc PR, Rosa JRBF, Gomes KA, Chiorato AF, Carbonell SAM, Garcia AA, Vianello RP, Benchimol-Reis LL. Genome-wide association studies of anthracnose and angular leaf spot resistance in common bean (Phaseolus vulgaris L.). PLoS ONE. 2016; 11: e0150506.

[14] Wu J, Zhu J, Wang L, Wang S. Genome-wide association study identifies NBS-LRR-encoding genes related with anthracnose and common bacterial blight in the common bean. Front Plant Sci. 2017; 8: 1398. 
[15] Fritsche-Neto R, Souza TLPO, Pereira HS, Faria LC, Melo LC, Novaes E, Brum, IJB, Jannink JL. Association mapping in common bean revealed regions associated with anthracnose and angular leaf spot resistance. Sci Agr. 2019; 76: 321-327.

[16] Vidigal Filho PS, Gonçalves-Vidigal MC, Vaz Bisneta MV, Souza VB, Gilio TAS, Calvi A, Lima LRL, Pastor-Corrales MA, Melotto M. Genome-wide association study of resistance to anthracnose and angular leaf spot in Brazilian Mesoamerican and Andean common bean cultivars. Crop Sci. 2020; 60: 2931-2950.

[17] Costa LC Nalin RS, Dias, MA, Ferreira ME, Song Q, Pastor-Corrales MA, Hurtado-Gonzales OP, Souza EA. Different loci control resistance to different isolates of the same race of Colletotrichum lindemuthianum in common bean. Theor Appl Genet. 2021; 134: 543-556.

[18] Nunes MPBA, Gonçalves-Vidigal, MC, Martins VSR, Xavier LFS, Valentini G, Vaz Bisneta M, Vidigal Filho OS. Relationship of Colletotrichum lindemuthianum races and resistance loci in the Phaseolus vulgaris L. genome. Crop Sci. 2021; 1-17.

[19] Balardin RS, Kelly JD. Interaction between Colletotrichum lindemuthianum races and gene pool diversity in Phaseolus vulgaris. J Amer Soc Hort Sci. 1998; 123: 1038-1047.

[20] Rodríguez-Guerra R, Ramírez-Rueda MT, de La Vega OM, Simpson J. Variation in genotype, pathotype and anastomosis groups of Colletotrichum lindemuthianum isolates from Mexico. Plant Pathol. 2003; 52: $228-235$.

[21] Pastor-Corrales MA. Estandarización de variedades diferenciales y de designación de razas de Colletotrichum lindemuthianum. Phytopathology. 1991; 81: 694.

[22] Blair MW, Pedraza F, Buendia HF, Gaitán-Solís E, Beebe SE, Gepts P, Tohme J. Development of a genome-wide anchored microsatellite map for common bean (Phaseolus vulgaris L.). Theor Appl Genet. 2003; 107: 1362-1374.

[23] Pallotta M, Warner P, Fox R, Kuchel H, Jefferies S, Langridge P. Marker assisted wheat breeding in the southern region of Australia. In Proc. 10th Int. Wheat Genet. Symp., 1-6 Sept. 2003. (Pogna, N. E., ed.). Paestum, Italy: Istituto Sperimentale per la Cerealicoltura, Rome, Italy. 789-791.

[24] Elshire RJ, Glaubitz JC, Sun Q, Poland JA, Kawamoto K, Buckler ES, Mitchell SE. A Robust: Simple genotyping-bysequencing (GBS) approach for high diversity. PLoS ONE. 2010; 16: e19379.

[25] Ariani A, Berny Mier y Teran JC, Gepts P. Genome-wide identification of SNPs and copy number variation in common bean (Phaseolus vulgaris L.) using genotyping-by-sequencing (GBS). Mol Breeding. 2016; 36: 1-11.

[26] Schmutz J, McClean P, Mamidi S, Wu G, Cannon S, Grimwood J, et al. A reference genome for common bean and genome-wide analysis of dual domestications. Nat Genet. 2014; 46: 707-713.

[27] Li H, Durbin R. Fast and accurate short read alignment with Burrows-Wheeler transform. Bioinformatics. 2009; 25: 1754-1760.

[28] Cabanski CR, Cavin K, Bizon C, Wilkerson MD, Parker JS, Wilhelmsen KC, Perou CM, Marron JS, Hayes DN. ReQON: a bioconductor package for recalibrating quality scores from next-generation sequencing data. BMC Bioinformatics. 2012; 13: 221.

[29] Cárdenas F, Adams MW, Andersen A. The genetic system for reaction of field beans (Phaseolus vulgaris L.) to infection by three physiologic races of Colletotrichum lindemuthianum. Euphytica. 1964; 13: 178-186.

[30] Pastor-Corrales MA, Otoya MM, Molina A, Singh SP. Resistance to Colletotrichum lindemuthianum isolates from Middle America and Andean South America in different common bean races. Plant Dis. 1995; 79: 63-67.

[31] Bradbury PJ, Zhang Z, Kroon DE, Casstevens TM, Ramdoss Y, Buckler ES. TASSEL: Software for association mapping of complex traits in diverse samples. Bioinformatics. 2007; 2: 2633-2635.

[32] Bannerot H. Résults de l'infection d'une collection de haricots par six races physiologiques d'anthracnose. Annales de l'amélioration des plantes. 1965; 15: 201-222.

[33] Fouilloux G. New races of bean anthracnose and consequences on our breeding programs. In: Maraite H, Meyer JA, eds. Diseases of Tropical Food Crops. Louvain-la-Neuve, Belgium: Université Catholique de Louvain. 1979; 221-235.

[34] Young RA, Melotto M, Nodari RO, Kelly JD. Marker-assisted dissection of the oligogenic anthracnose resistance in the common bean cultivar "G 2333". Theor Appl Genet. 1998; 96: 87-94. 
[35] Geffroy V, Sicard D, Oliveira JCF, Sévignac M, Cohen S, Gepts P, Neema C, Langin T, Dron, M. Identification of an ancestral resistance gene cluster involved in the coevolution process between Phaseolus vulgaris and its fungal pathogen Colletotrichum lindemuthianum. Mol Plant Microbe Interact. 1999; 12: 774-784.

[36] Gonçalves-Vidigal MC, Cruz AS, Lacanallo GF, Vidigal Filho PS, Sousa LL, Pacheco CMNA, McClean P, Gepts P, Pastor-Corrales MA. Co-segregation analysis and mapping of the anthracnose Co-10 and angular leaf spot PhgON disease-resistance genes in the common bean cultivar Ouro Negro. Theor Appl Genet. 2013; 126: 2245 -2255.

[37] Murube E, Campa A, Ferreira JJ. Integrating genetic and physical positions of the anthracnose resistance genes described in bean chromosomes Pv01 and Pv04. PLoS ONE. 2019; 14: e0212298.

[38] Valentini G, Goncalves-Vidigal MC, Hurtado Gonzales OP, de Lima Castro SA, Cregan PB, Song Q, Pastor-Corrales, MA. High-resolution mapping reveals linkage between genes in common bean cultivar Ouro Negro conferring resistance to the rust, anthracnose, and angular leaf spot diseases. Theor Appl Genet. 2017; 130: 1705-1722.

[39] Campa A, Giraldez R, Ferreira. Genetic analysis of the resistance to eight anthracnose races in the common bean differential cultivar Kaboon. Phytopathology. 2011; 101: 757-764.

[40] Campa A, Trabanco N, Ferreira JJ. Identification of clusters that condition resistance to anthracnose in the common bean differential cultivars AB 136 and MDRK. Phytopathology. 2017; 107: 1515-1521.

[41] Rodríguez-Suárez C, Ferreira JJ, Campa A, Pañeda A, Giraldez R. Molecular mapping and intra-cluster recombination between anthracnose race-specific resistance genes in the common bean differential cultivars Mexico 222 and Widusa. Theor Appl Genet. 2008; 116: 807-814.

[42] Rodríguez-Suárez C, Méndez-Vigo B, Pañeda A, Ferreira JJ, Giraldez R. A genetic linkage map of Phaseolus vulgaris L. and localization of genes for specific resistance to six races of anthracnose (Colletotrichum lindemuthianum). Theor Appl Genet. 2007; 114: 713-722.

[43] Coimbra-Gonçalves GK, Gonçalves-Vidigal MC, Coelho RT, Valentini G, Vidigal Filho PS, Lacanallo GF, Elias HT. Characterization and mapping of anthracnose resistance gene in Mesoamerican common bean cultivar Crioulo 159. Crop Sci. 2016; 56: 1-12.

[44] Sousa LL, Gonçalves AO, Gonçalves-Vidigal MC, Lacanallo GF, Fernandez AC, Awale H, Kelly JD. Genetic characterization and mapping of anthracnose resistance of Corinthiano common bean landrace cultivar. Crop Sci. 2015; 55: 1-11.

[45] Jones DG, Dangl JL. The plant immune system. Nature. 2006; 444: 323-329.

[46] Zipfel C. Plant pattern-recognition receptors. Trends Immunol. 2014; 35: 345- 351.

[47] Karthikeyan A, Li K, Jiang H, Ren R, Li C, Zhi H, Chen S, Gai J. Inheritance, fine-mapping, and candidate gene analyses of resistance to soybean mosaic virus strain SC5 in soybean. Mol Genet Genomics. 2017; 292: 811-822.

[48] Kiba T, Naitou T, Koizumi N, Yamashino T, Sakakibara H, Mizuno T. Combinatorial microarray analysis revealing Arabidopsis genes implicated in cytokinin responses through the His $\rightarrow$ Asp phosphorelay circuitry. Plant Cell Physiol. 2005; 46: 339-355.

[49] Restrepo-Montoya D, Brueggeman R, McClean PE, Osorno JM. Computational identification of receptor-like kinases "RLK" and receptor-like proteins "RLP" in legumes. BMC Genomics. 2020; $21: 459$. https://doi.org/10.1186/s12864-020-06844-z

[50] Sekhwal MK, Li P, Lam I, Wang X, Cloutier S, You FM. Disease resistance gene analogs (RGAs) in plants. Int J Mol Sci. 2015; 16: 19248-19290.

[51] Sun J, Li L, Wang P, Zhang S, Wu J. Genome-wide characterization, evolution, and expression analysis of the leucine-rich repeat receptor-like protein kinase (LRR-RLK) gene family in Rosaceae genomes. BMC Genomics. 2017; 18: 763.

[52] Sheen J. Ca2+-dependent protein kinases and stress signal transduction in plants. Sci. 1996; 274: 1900-1902.

[53] Romeis T, Ludwig AA, Martin R, Jones JD. Calcium-dependent protein kinases play an essential role in a plant defence response. EMBO J. 2001; 20: 5556-5567.

[54] Sessa G, Meller Y, Fluhr RA. GCC element and a G-box motif participate in ethylene-induced expression of the PRB-1b gene. Plant Mol Biol. 1995; 28: 145-153.

[55] Kobe B, Kajava AV. The leucine-rich repeat as a protein recognition motif. Curr Opin Struc Biol. 2001; 11: 725732 . 
[56] Cui H, Tsuda K, Parker JE. Effector-triggered immunity: from pathogen perception to robust defense. Annu Rev Plant Biol. 2015; 66: 487-511.

[57] Oblessuc PR, Francisco C, Melotto M. The Co-4 locus on Chromosome Pv08 contains a unique cluster of 18 COK4 genes and is regulated by immune response in common bean. Theor Appl Genet. 2015; 128: 1193-1208.

[58] Lacanallo GF, Gonçalves-Vidigal MC. Mapping of an Andean gene for anthracnose resistance (Co-13) in common bean (Phaseolus vulgaris L.) Jalo Listras Pretas landrace. Aust J Crop Sci. 2015; 9: 394-400.

[59] de Lima Castro SA, Gonçalves-Vidigal MC, Gilio TAS, Lacanallo GF, Valentini G, Martins VSR, Song Q, Galván MZ, Hurtado-Gonzales OP, Pastor-Corrales MA. Genetics and mapping of a new anthracnose resistance locus in Andean common bean Paloma. BMC Genomics. 2017; 18: 306.

[60] Manna S. An overview of pentatricopeptide repeat proteins and their application. Biochimie. 2015 ; 113 : 93-99.

[61] Kuroda H, Takahashi N, Shimada H, Seki M, Shinozaki K, Matsui M. Classification and expression analysis of Arabidopsis F-Box-containing protein genes. Plant Cell Physiol. 2002; 43: 1073-1085.

\section{Supporting information}

Supplemental material is available online for this article.
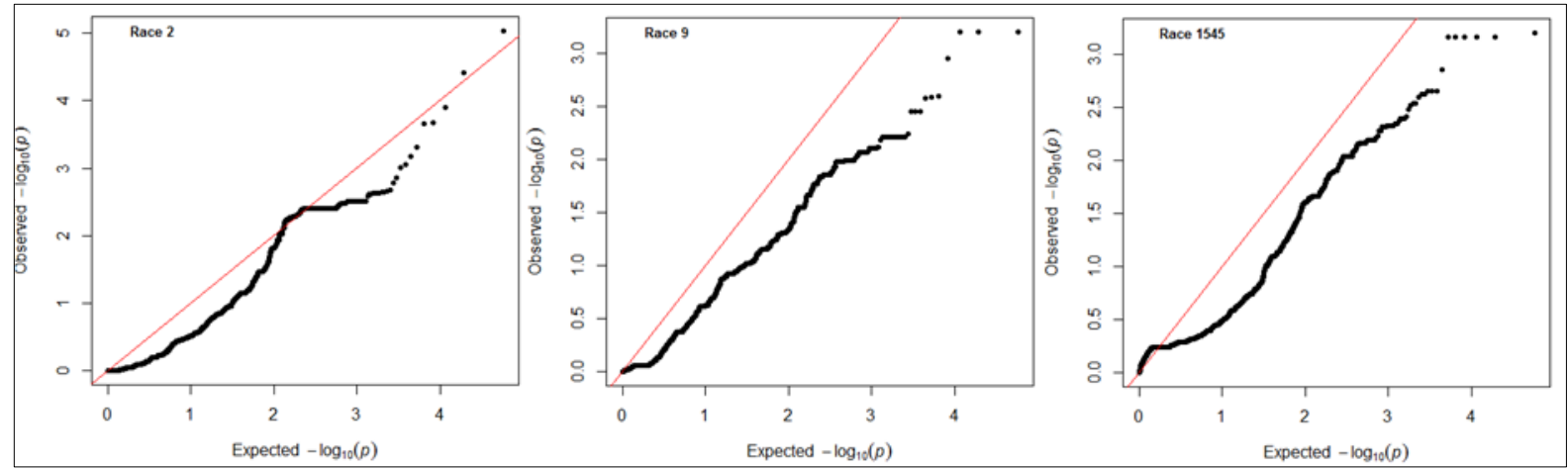

S1 Figure QQ plot showing SNPs and p-values from GWAS for anthracnose resistance against race 2, 9 and 1545, respectively.

S1 Table Identification of the 89 common bean accessions from Brazil evaluated in this study.

\begin{tabular}{|l|l|l|l|l|l|l|l|l|}
\hline Code & $\begin{array}{l}\text { Common } \\
\text { name }\end{array}$ & State & City & Latitude & Longitude & $\begin{array}{l}\text { Height } \\
\text { (m) }\end{array}$ & $\begin{array}{l}\text { Commercial } \\
\text { group }\end{array}$ & $\begin{array}{l}\text { Gene } \\
\text { pool }\end{array}$ \\
\hline BL_1 & Brigida & PE & Recife & -8.058880 & -34.880833 & 4 & Carioca & M \\
\hline BL_2 & Cocão & PE & Recife & -8.058880 & -34.880833 & 4 & Others & A \\
\hline BL_3 & Bagajó & SE & Poço Verde & -10.707777 & -38.182777 & 268 & Others & A \\
\hline BL_5 & Canarinho & PE & Lajedo & -8.663888 & -36.336666 & 661 & Others & A \\
\hline BL_6 & $\begin{array}{l}\text { Rosinha } \\
\text { Claro }\end{array}$ & PE & Calçado & -8.741944 & -36.333888 & 643 & Rosinha & M \\
\hline BL_7 & Chita fina & PE & São João & -8.875833 & -36.366944 & 716 & Others & A \\
\hline BL_8 & Jaula & PE & São João & -8.890277 & -36.492770 & 842 & Others & A \\
\hline BL_9 & Pintado & PE & Ibimirim & -8.540555 & -37.690277 & 401 & Others & A \\
\hline BL_10 & Bolinha & PE & Lajeado & -8.540555 & -36.320000 & 532 & Mulatinho & M \\
\hline BL_11 & Praia & SE & Poço Verde & -8.053888 & -34.880833 & 268 & Others & A \\
\hline BL_12 & Camarão & PE & Calçado & -8.741944 & -36.333888 & 643 & Others & A \\
\hline
\end{tabular}


World Journal of Advanced Research and Reviews, 2021, 12(01), 020-040

\begin{tabular}{|c|c|c|c|c|c|c|c|c|}
\hline BL_13 & BSF-1 Creme & $\mathrm{PE}$ & $\begin{array}{l}\text { Belém do São } \\
\text { Francisco }\end{array}$ & -8.753888 & -38.963888 & 305 & Others & A \\
\hline BL_14 & $\begin{array}{l}\text { BSF-2 Pingo } \\
\text { de Ouro }\end{array}$ & $\mathrm{PE}$ & $\begin{array}{l}\text { Belém do São } \\
\text { Francisco }\end{array}$ & -8.053888 & -34.880830 & 305 & Carioca & $\mathrm{M}$ \\
\hline BL_15 & $\begin{array}{l}\text { BSF-3 Fogo } \\
\text { na serra }\end{array}$ & $\mathrm{PE}$ & $\begin{array}{l}\text { Belém do São } \\
\text { Francisco }\end{array}$ & -8.053888 & -34.880830 & 305 & Others & A \\
\hline BL_16 & $\begin{array}{l}\text { Brilhoso } \\
\text { Mulatinho }\end{array}$ & $\mathrm{PE}$ & São João & -8.875833 & -36.366944 & 716 & Mulatinho & M \\
\hline BL_19 & $\begin{array}{ll}\text { IPA } & 1 \\
\text { Mulatinho } & \end{array}$ & $\mathrm{PE}$ & Recife & -8.058880 & -34.880833 & 4 & Mulatinho & M \\
\hline BL_24 & $\begin{array}{l}\text { Mulatinho de } \\
\text { Cacho }\end{array}$ & $\mathrm{PB}$ & Arara & -6.827777 & -35.757777 & 467 & Mulatinho & M \\
\hline BL_25 & Mulatinho & $\mathrm{PE}$ & Jucati & -8.705833 & -36.488888 & 820 & Mulatinho & M \\
\hline BL_27 & Mulatão & $\mathrm{PE}$ & Bezerros & -8.889999 & -36.492777 & 470 & Mulatinho & A \\
\hline BL_30 & Flor Azul & $\mathrm{PE}$ & Águas Belas & -9.110833 & -37.122777 & 376 & Mulatinho & M \\
\hline BL_31 & Bico de ouro & $\mathrm{PE}$ & Águas Belas & -9.110833 & -37.122777 & 376 & Mulatinho & M \\
\hline BL_34 & Feijão Laje & $\mathrm{PB}$ & $\begin{array}{l}\text { São Miguel de } \\
\text { Itaipu }\end{array}$ & -7.250000 & -35.210000 & 45 & Mulatinho & M \\
\hline BL_35 & Caiaminha & $\mathrm{PE}$ & Calçado & -8.741944 & -36.333888 & 643 & Rosinha & M \\
\hline BL_50 & CLPE17 & $\mathrm{PE}$ & Lajedo & -8.663888 & -36.336666 & 661 & Preto & M \\
\hline BL_66 & $\begin{array}{l}\text { Feijão } \\
\text { Carioca }\end{array}$ & $\mathrm{PE}$ & Caruaru & -8.282777 & -35.975833 & 554 & Carioca & M \\
\hline BL_67 & $\begin{array}{l}\text { Feijão } \\
\text { Carioca }\end{array}$ & $\mathrm{PE}$ & $\begin{array}{l}\text { Sta Maria do } \\
\text { Cambucá }\end{array}$ & -7.840000 & -35.901944 & 494 & Carioca & M \\
\hline BL_69 & $\begin{array}{l}\text { Feijão } \\
\text { Mulatinho }\end{array}$ & $\mathrm{PE}$ & Arcoverde & -8.420833 & -37.061388 & 663 & Mulatinho & M \\
\hline BL_70 & $\begin{array}{l}\text { Feijão } \\
\text { Carioca }\end{array}$ & $\mathrm{PE}$ & Vertentes & -7.902777 & -35.987777 & 401 & Carioca & M \\
\hline BL_71 & $\begin{array}{l}\text { Feijão } \\
\text { Mulatinho }\end{array}$ & $\mathrm{PE}$ & Arcoverde & -8.420833 & -37.061388 & 663 & Mulatinho & M \\
\hline BL_74 & Favita & $\mathrm{PE}$ & São João & -8.875833 & -36.366944 & 716 & Others & A \\
\hline BL_75 & Favita & $\mathrm{PE}$ & São João & -8.875833 & -36.366944 & 716 & Others & A \\
\hline BL_76 & $\begin{array}{l}\text { Feijão } \\
\text { Carioca }\end{array}$ & $\mathrm{PE}$ & São João & -8.875833 & -36.366944 & 716 & Carioca & M \\
\hline BL_77 & Enxofre & $\mathrm{PE}$ & São João & -8.875833 & -36.366944 & 716 & Enxofre & A \\
\hline BL_78 & Favita & $\mathrm{PE}$ & São João & -8.875833 & -36.366944 & 716 & Others & A \\
\hline BL_79 & Favita & $\mathrm{PE}$ & São João & -8.875833 & -36.366944 & 716 & Others & $\mathrm{A}$ \\
\hline BL_80 & Feijão Preto & $\mathrm{PE}$ & São João & -8.875833 & -36.366944 & 716 & Preto & M \\
\hline BL_81 & Feijão Preto & $\mathrm{PE}$ & São João & -8.875833 & -36.366944 & 716 & Preto & M \\
\hline BL_82 & $\begin{array}{l}\text { Feijão } \\
\text { Carioca }\end{array}$ & $\mathrm{PE}$ & São João & -8.875833 & -36.366944 & 716 & Carioca & M \\
\hline BL_83 & Feijão Preto & $\mathrm{PE}$ & Lajedo & -8.663888 & -36.336666 & 661 & Preto & M \\
\hline BL_84 & Feijão Preto & $\mathrm{PE}$ & Jucati & -8.705833 & -36.488888 & 820 & Preto & M \\
\hline BL_85 & $\begin{array}{l}\text { Feijão } \\
\text { Carioca }\end{array}$ & $\mathrm{PE}$ & Jucati & -8.705833 & -36.488888 & 820 & Carioca & M \\
\hline BL_86 & Feijão Preto & $\mathrm{PE}$ & Jupi & -8.711944 & -36.415000 & 782 & Preto & M \\
\hline
\end{tabular}


World Journal of Advanced Research and Reviews, 2021, 12(01), 020-040

\begin{tabular}{|c|c|c|c|c|c|c|c|c|}
\hline BL_87 & $\begin{array}{l}\text { Feijão } \\
\text { Carioca }\end{array}$ & $\mathrm{PE}$ & Arcoverde & -8.420833 & -37.061388 & 663 & Carioca & M \\
\hline BL_88 & $\begin{array}{l}\text { Feijão } \\
\text { Mulatinho }\end{array}$ & $\mathrm{PE}$ & São João & -8.875833 & -36.366944 & 716 & Mulatinho & M \\
\hline BL_90 & Feijão Preto & $\mathrm{PE}$ & São João & -8.875833 & -36.366944 & 716 & Preto & M \\
\hline BL_91 & Feijão Preto & $\mathrm{PE}$ & São João & -8.875833 & -36.366944 & 716 & Preto & M \\
\hline BL_92 & $\begin{array}{l}\text { Feijão } \\
\text { Mulatinho }\end{array}$ & $\mathrm{PE}$ & Arcoverde & -8.420833 & -37.061388 & 663 & Mulatinho & M \\
\hline BL_93 & $\begin{array}{l}\text { Feijão } \\
\text { Colorido }\end{array}$ & $\mathrm{PE}$ & Casinha & -7.741111 & -35.721111 & 390 & Others & A \\
\hline BL_94 & Favita & $\mathrm{PE}$ & Lajedo & -8.663888 & -36.336666 & 661 & Others & A \\
\hline BL_95 & Feijão Preto & $\mathrm{PE}$ & Calçado & -8.741944 & -36.333888 & 643 & Preto & M \\
\hline BL_96 & $\begin{array}{l}\text { Feijão } \\
\text { Mulatinho }\end{array}$ & $\mathrm{PE}$ & Caruaru & -8.282777 & -35.975833 & 554 & Mulatinho & M \\
\hline BL_99 & Feijão Preto & $\mathrm{PE}$ & Caruaru & -8.282777 & -35.975833 & 554 & Preto & M \\
\hline BL_100 & $\begin{array}{l}\text { Feijão } \\
\text { Mulatinho }\end{array}$ & $\mathrm{PE}$ & Calçado & -8.741944 & -36.333888 & 643 & Mulatinho & M \\
\hline BL_102 & Feijão Preto & $\mathrm{PE}$ & São Caetano & -8.325833 & -36.142777 & 552 & Preto & M \\
\hline BL_103 & Feijão Preto & $\mathrm{PE}$ & São Caetano & -8.325833 & -36.142777 & 552 & Preto & M \\
\hline BL_104 & $\begin{array}{l}\text { Feijão } \\
\text { Colorido }\end{array}$ & $\mathrm{PE}$ & Surubim & -7.831944 & -35.755833 & 394 & Others & M \\
\hline BL_105 & $\begin{array}{l}\text { Feijão } \\
\text { Mulatinho }\end{array}$ & $\mathrm{PE}$ & $\begin{array}{l}\text { Sta Maria do } \\
\text { Cambucá }\end{array}$ & -7.840000 & -35.901944 & 494 & Mulatinho & M \\
\hline BL_106 & $\mathrm{BG}-4$ & MT & Cáceres & -15.799572 & -57.385088 & 180 & Mulatinho & $\mathrm{M}$ \\
\hline BL_107 & BG-9 & MT & $\begin{array}{l}\text { Mirassol do } \\
\text { Oeste }\end{array}$ & -15.583333 & -57.979166 & 285 & Mulatinho & M \\
\hline BL_108 & $\mathrm{BG}-13$ & MT & Cáceres & -15.731691 & -57.351783 & 151 & Mulatinho & M \\
\hline BL_109 & BG-17 & MT & Cáceres & -16.261083 & -58.292461 & 202 & Mulatinho & M \\
\hline BL_110 & BG-18 & MT & Cáceres & -16.251022 & -58.294869 & 186 & Mulatinho & M \\
\hline BL_111 & BG-23 & MT & Cáceres & -15.998333 & -57.481666 & 311 & Mulatinho & M \\
\hline BL_165 & Pitanga & $\mathrm{PR}$ & Pitanga & -24.729000 & -51.721425 & 829 & Others & A \\
\hline BL_166 & Corinthiano & $\mathrm{PR}$ & Loanda & -22.971027 & -53.106013 & 344 & Others & A \\
\hline BL_167 & Perla & & & & & & Others & A \\
\hline BL_168 & JaloVermelho & PR & $\begin{array}{l}\text { Capitão } \\
\text { Leônidas } \\
\text { Marques }\end{array}$ & -25.484708 & -53.583041 & 380 & Others & A \\
\hline BL_170 & $\begin{array}{l}\text { JaloListras } \\
\text { Pretas }\end{array}$ & $\mathrm{PR}$ & Nova Santa Rosa & -24.428666 & -53.971819 & 480 & Others & A \\
\hline BL_171 & Jalo EEP 558 & & & & & & Others & A \\
\hline BL_172 & BGF 20 & $\mathrm{PR}$ & Terra Rica & -22.688794 & -52.61755 & 381 & Others & A \\
\hline BL_174 & Juriti & $\mathrm{PR}$ & Londrina & -23.354722 & -51.16472 & 573 & Carioca & $\mathrm{M}$ \\
\hline BL_177 & Awauna UEM & $\mathrm{PR}$ & Maringá & -23.435833 & -51.89472 & 565 & Preto & $\mathrm{M}$ \\
\hline BL_181 & MT 50G2 & MT & $\begin{array}{l}\text { Mirassol do } \\
\text { Oeste }\end{array}$ & -15.496902 & -58.044955 & 169 & Rosinha & M \\
\hline
\end{tabular}


World Journal of Advanced Research and Reviews, 2021, 12(01), 020-040

\begin{tabular}{|c|c|c|c|c|c|c|c|c|}
\hline BL_183 & MT 55 & MT & $\begin{array}{l}\text { Mirassol do } \\
\text { Oeste }\end{array}$ & -15.505158 & -58.059069 & 172 & & M \\
\hline BL_184 & MT 57G1 & MT & $\begin{array}{l}\text { Mirassol do } \\
\text { Oeste }\end{array}$ & -15.521236 & -58.049863 & 184 & Rosinha & M \\
\hline BL_186 & MT 62 & MT & $\begin{array}{l}\text { Mirassol do } \\
\text { Oeste }\end{array}$ & -15.505158 & -58.059069 & 172 & & M \\
\hline BL_187 & MT 73G1 & MT & $\begin{array}{l}\text { Mirassol do } \\
\text { Oeste }\end{array}$ & -15.538369 & -58.047044 & 186 & Rosinha & M \\
\hline BL_189 & MT 79 & MT & $\begin{array}{l}\text { Mirassol do } \\
\text { Oeste }\end{array}$ & -15.538369 & -58.047044 & 186 & & M \\
\hline BL_199 & Enxofre & PE & Lajedo & -8.663888 & -36.336666 & 661 & Enxofre & A \\
\hline BL_216 & $\begin{array}{l}\text { Feijão } \\
\text { Carioca }\end{array}$ & $\mathrm{PE}$ & $\begin{array}{l}\text { Santa Maria do } \\
\text { Cambucá }\end{array}$ & -7.840000 & -35.901944 & 494 & Carioca & M \\
\hline BL_220 & Jalo Pintado 2 & PR & $\begin{array}{l}\text { Capitão } \\
\text { Leônidas } \\
\text { Marques }\end{array}$ & -25.484708 & -53.583041 & 380 & Others & A \\
\hline BL_221 & AND277 & & & & & & Others & A \\
\hline BL_225 & $\begin{array}{l}\text { Sempre } \\
\text { Assim Branco }\end{array}$ & $\mathrm{PE}$ & Águas Belas & -9.110833 & -37.122777 & 376 & Branco & M \\
\hline BL_226 & CLPE3 & PE & São João & -8.875833 & -36.366944 & 716 & Preto & M \\
\hline BL_227 & CLPE4 & PE & São João & -8.875833 & -36.366944 & 716 & Preto & M \\
\hline BL_228 & CLPE8 & PE & São João & -8.875833 & -36.366944 & 716 & Preto & M \\
\hline BL_229 & CLPE10 & $\mathrm{PE}$ & Caetés & -8.772777 & -36.622777 & 849 & Preto & M \\
\hline BL_230 & CLPE11 & PE & Jucati & -8.705833 & -36.488888 & 820 & Preto & M \\
\hline BL_234 & FeijãoPreto & PE & Calçado & -8.741944 & -36.333888 & 643 & Preto & M \\
\hline
\end{tabular}

A - Andean, M - Mesoamerican, PE - Pernambuco, PB - Paraíba, SE - Sergipe, PR - Paraná, MT - Mato Grosso. 